IZA DP No. 6849

Separations, Sorting and Cyclical Unemployment

Andreas I. Mueller

September 2012

Forschungsinstitut zur Zukunft der Arbeit Institute for the Study of Labor 


\title{
Separations, Sorting and Cyclical Unemployment
}

\author{
Andreas I. Mueller \\ Columbia University \\ and IZA
}

\section{Discussion Paper No. 6849 \\ September 2012}

\author{
IZA \\ P.O. Box 7240 \\ 53072 Bonn \\ Germany \\ Phone: +49-228-3894-0 \\ Fax: +49-228-3894-180 \\ E-mail: iza@iza.org
}

\begin{abstract}
Any opinions expressed here are those of the author(s) and not those of IZA. Research published in this series may include views on policy, but the institute itself takes no institutional policy positions.

The Institute for the Study of Labor (IZA) in Bonn is a local and virtual international research center and a place of communication between science, politics and business. IZA is an independent nonprofit organization supported by Deutsche Post Foundation. The center is associated with the University of Bonn and offers a stimulating research environment through its international network, workshops and conferences, data service, project support, research visits and doctoral program. IZA engages in (i) original and internationally competitive research in all fields of labor economics, (ii) development of policy concepts, and (iii) dissemination of research results and concepts to the interested public.
\end{abstract}

IZA Discussion Papers often represent preliminary work and are circulated to encourage discussion. Citation of such a paper should account for its provisional character. A revised version may be available directly from the author. 
IZA Discussion Paper No. 6849

September 2012

\section{ABSTRACT}

\section{Separations, Sorting and Cyclical Unemployment}

This paper establishes a new fact about the compositional changes in the pool of unemployed over the U.S. business cycle and evaluates a number of theories that can potentially explain it. Using micro-data from the Current Population Survey for the years 1962-2011, it documents that in recessions the pool of unemployed shifts towards workers with high wages in their previous job. Moreover, it shows that these changes in the composition of the unemployed are mainly due to the higher cyclicality of separations for high-wage workers, and not driven by differences in the cyclicality of job-finding rates. A search-matching model with endogenous separations and worker heterogeneity in terms of ability has difficulty in explaining these patterns, but an extension of the model with creditconstraint shocks does much better in accounting for the new facts.

JEL Classification: E24, E32, J63

Keywords: $\quad$ sorting, unemployment, business cycles, search-matching, vacancies

Corresponding author:

Andreas I. Mueller

Columbia Business School

Columbia University

Uris Hall

3022 Broadway

New York, NY 10027

USA

E-mail: amueller@columbia.edu

\footnotetext{
* I am grateful to Per Krusell, John Hassler, Torsten Persson, Alan B. Krueger, Mark Aguiar, Dale Mortensen, Jonathan Parker, Mark Bils, Yongsung Chang, Erik Hurst, Thijs van Rens, Fabrizio Zilibotti, Pascal Michaillat, Aysegul Sahin, Mike Elsby, Almut Balleer, Phillippe Aghion, Valerie A. Ramey, Toshihiko Mukoyama, Gueorgui Kambourov, Guillermo Ordonez, Steinar Holden, Tobias Broer, Ethan Kaplan, Mirko Abbritti, Shon Ferguson, David von Below, Erik Meyersson, Daniel Spiro, Ronny Freier and participants at seminars at Columbia GSB, Northwestern University, the University of Edinburgh, the Federal Reserve Bank of Richmond, the Federal Reserve Bank of New York, the University of Western Ontario, Toulouse School of Economics, Aarhus University, the University of Essex, the University of Southampton, the University of Lausanne, McGill University, University of Montreal, the Bank of England, the NordMac symposium 2010 and the Econometric Society European Winter Meeting for very helpful comments and ideas, and to Handelsbanken's Research Foundations and the Mannerfelt Foundation for financial support.
} 


\section{Introduction}

This paper establishes a new fact about the compositional changes in the pool of unemployed over the U.S. business cycle and evaluates a number of theories that can potentially explain it. Using micro data from the Current Population Survey (CPS) for the years 1962-2011, I document that in recessions the pool of unemployed shifts towards workers with high wages in their previous job. This cyclical pattern is robust to many different empirical specifications. Controlling for observable characteristics such as education, experience, occupation etc. in the wage, I show that the share of unemployed with high residual wages still increases in recessions, although the magnitude of the increase is smaller than for the raw wage measure. This finding suggests that both observed and unobserved factors explain the shift towards high-wage workers in recessions. I also investigate whether the compositional shift is due to differences in the cyclicality of separation or job-finding rates across wage groups, and find that the compositional shift is almost entirely driven by separations.

These empirical patterns may appear to contradict findings from a related literature on the cyclicality of real wages. Specifically, Solon, Barsky and Parker (1994) documented that the measured cyclicality of aggregate real wages is downward biased, because the typical employed person is of higher ability in recessions. Hines, Hoynes and Krueger (2001), however, showed that Solon, Barsky and Parker's result relies on the weighting of aggregate real wages by hours worked. With unweighted wage data, composition bias has almost no effect on the cyclicality of real wages, suggesting that is not the composition of the employed that changes over the business cycles but rather the hours worked by different skill groups. Moreover, changes in the composition of the employed do not necessarily translate into changes in the pool of unemployed in the opposite direction if the average quality between the pools differs. In fact, I show that large shifts towards high-wage workers in the pool of unemployed are consistent with small shifts towards high-wage workers in the pool of employed.

My empirical findings have potentially important implications for models of aggregate fluctuations in the labor market, as changes in the pool of unemployed feed back into firms' incentives for hiring. Contrary to Pries (2008), who assumes that the pool of unemployed shifts towards low-ability workers, shifts towards high-ability workers in recessions lead to a dampening of productivity shocks. The reason is that when unemployment shifts towards the more able, the probability that a firm finds a worker of high ability goes up, which raises the returns to posting vacancies. This poses an additional challenge to the recent literature on the "unemployment volatility puzzle" (see Shimer, 2005), as shifts towards high-ability workers in recessions may dampen the response of hiring and unemployment to aggregate productivity shocks.

Given the importance of the new fact I document in the first part of the paper, the second 
part of the paper tries to explain it. For this purpose, I first set up a search-matching model with match-specific productivity shocks, endogenous separations and worker heterogeneity in terms of ability. ${ }^{1}$ The baseline model, however, implies shifts in the pool of unemployed towards low-ability workers in recessions, which is inconsistent with the new facts. I also explore other calibrations of the model, as well as models with different types of worker heterogeneities such as differences in bargaining power or home production. All these models, however, have difficulties in replicating the key facts summarized above. Therefore, I offer two extensions of the model that can potentially explain the more cyclical nature of separations for high-ability workers.

One explanation is that many layoffs in downturns occur due to firm and plant death. These shocks affect workers indiscriminately of type and thus lead to larger increases in separations in percentage terms for those with lower average separation rates (i.e., high-ability workers). The model, however, cannot fully explain the higher cyclicality of separations for high-ability workers because these firm death shocks are not cyclical enough.

Thus, I propose another extension of the model with credit shocks, where firms are constrained to produce positive cash flows in recessions. This also produces more cyclical separations for high-ability workers. The idea is that it is more difficult to obtain outside financing in recessions as liquidity dries up in financial markets. In the baseline model with efficient separations, worker-firm matches produce negative cash flows at the productivity threshold where separations occur. The firm is willing to pay the worker above current match productivity, because it is compensated by expected positive future cash flows. Thus, if firms face constraints on their cash flows in recessions, workers and firms may separate even though it would be in the interest of both parties to continue the relationship. This mechanism is stronger for high-ability workers, because they produce larger negative cash flows at the efficient (unconstrained) separation threshold. Therefore, separations of these workers are more sensitive to a tightening of credit. As a result, the model produces more cyclical separations for high-ability workers, consistent with the empirical patterns in the U.S. data.

The remainder of the paper is organized as follows. Section 2 describes the CPS data and carries out the empirical analysis. Section 3 sets up the search-matching model, discusses alternative calibration strategies, and studies the model with firm and plant death. Section 4 extends the model with credit-constraint shocks and Section 5 concludes the paper.

\footnotetext{
${ }^{1}$ Bils, Chang and Kim (2012) also study the cyclicality of separations for different wage and hours groups. However, they pay little attention to compositional changes in the pool of unemployed. See also Section 2 below for a discussion of their empirical results from the Survey of Income and Program Participation (SIPP).
} 


\section{Data}

The empirical analysis in this paper is based on U.S. micro data from the Current Population Survey (CPS) for the period 1962-2011. The CPS is the main labor force survey for the U.S., representative of the population aged 15 and older. It has a rotating panel structure, where households are surveyed in four consecutive months, rotated out of the panel for eight months, and then surveyed again for another four consecutive months, as illustrated in Figure 1. Note that the CPS records the labor-force status for each person in the sample each month. Weekly hours and earnings, however, are collected only in the fourth and eighth interview of the survey, referred to as the Outgoing Rotation Groups (ORG).

Figure 1: CPS panel structure by month and interview number

\begin{tabular}{|c|c|c|c|c|c|c|c|c|c|c|c|c|c|c|c|c|}
\hline Month & 1 & 2 & 3 & 4 & 5 & 6 & 7 & 8 & 9 & 10 & 11 & 12 & 13 & 14 & 15 & 16 \\
\hline Interview & 1 & 2 & 3 & 4 & & & & & & & & & 5 & 6 & 7 & 8 \\
\hline
\end{tabular}

The empirical analysis proceeds with two different data sources: First, I use data from the CPS ORG and monthly files to estimate monthly transition probabilities from employment to unemployment and vice versa for the period 1979-2008. Second, to extend the analysis to the period before 1979, I use data from the CPS March supplement for the period 19622011. The march supplement collects data on wage income from the last year for those currently unemployed, and can be used to replicate the main statistic of the compositional changes in the pool of unemployed, but it does not allow for an analysis of monthly transition probabilities as it is collected only once per year.

\subsection{Sample Criteria and Measurement}

CPS Outgoing Rotation Group (ORG) and monthly data (1979-2008) The main focus of the empirical analysis is on the wage of those who lose their job and become unemployed. Wage data is available only for the fourth and the eighth interview of each household. I restrict my sample to all individuals with available wage data from the fourth interview and analyze the employment outcomes in subsequent months. I do not use wage data from the eighth interview as this is the final interview in the CPS panel and I want to avoid possible selection effects associated with including wages after job loss. ${ }^{2}$

I restrict my sample to individuals aged 19 to 64 who worked in the private sector, are not self-employed and not self-incorporated. I also trim the sample for outliers excluding

\footnotetext{
${ }^{2}$ The main concern is that individuals who separate in recessions tend to have lower wages on their new job, because it has been documented that wages for new hires are more responsive to the business cycle. See, e.g., Bils (1985) or, more recently, Haefke, Sonntag and van Rens (2012).
} 
individuals with a wage above the 99.75 th or below the 0.25 th percentile each year and individuals with weekly hours below 5 or above 80 . The total sample size is 1,308,385 individuals, where each individual has up to three monthly transitions between labor market states (between interviews 5 to 6,6 to 7 and 7 to 8 ). Out of these 1,308,385 individuals, 84,193 experienced at least one month of unemployment in interview months 5-8.

The CPS does not follow individuals who move out from an address surveyed in a previous month. ${ }^{3}$ This gives rise to substantial attrition between the fourth interview when individuals report their wage and the interviews 9, 10, 11 and 12 months later (as shown by Figure 1, there is a gap of 8 months between the 4 th and the 5 th interview): $27.8 \%$ of the individuals in my sample had no match in interviews 5-8. Similarly to Bleakly, Ferris and Fuhrer (1999), I adjust the survey weights to account for attrition. More precisely, I run a logit regression of the likelihood of remaining in the sample for interviews 5 to 8 on observable characteristics (such as sex, age, education, race and marital status) for each year, and multiply the existing survey weight with the inverse of the predicted value of the logit regression. This deflates the weight for groups and years with low attrition rates. ${ }^{4}$

The selected sample excludes unemployed individuals who have been unemployed for more than 12 months. This may lead to biases in the estimates of the average and the cyclicality of job findings rates. Notice, however, that the median duration of unemployment was less than three months for the entire sample period according to official statistics of the Bureau of Labor Statistics (BLS), and the fraction of those with unemployment durations above one year averaged only $8.8 \%$ over the sample period with a maximum of $13.3 \%$ in $1983 .{ }^{5}$ This suggests that the constraint imposed by the sample-selection criterion is relatively minor. I do not extend my analysis to the most recent period because the share of long-term unemployed increased dramatically in the recent recession.

Finally, the sample does not include those who were classified as out of the labor force at the time of their 4th CPS interview. For this reason, movements from out of the labor force into unemployement are not included in my sample. ${ }^{6}$ As argued by Shimer (2007) and others, movements between out of the labor force and unemployment are relatively acyclical and contribute little to the overall variation in unemployment. Naturally, it is still possible that movements from out of the labor force into unemployment are different across groups and that these differences cancel out in the aggregate. In any event, movements from out of

\footnotetext{
${ }^{3}$ See the data appendix for details on the merging procedure.

${ }^{4}$ Abowd and Zellner (1985) propose a procedure of reweighing the data that minimizes the difference between the stocks implied by the matched worker flow data and the official CPS stocks. This procedure is not available here because the CPS does not report the stocks of unemployed by wage on the previous job.

${ }^{5}$ These numbers are taken from the OECD's statistics of "Incidence of unemployment by duration".

${ }^{6}$ However, it is possible to analyse transitions in the opposite direction from unemployment to out of the labor force, see Tabel 3 below.
} 
the labor force into unemployment are another potential margin of cyclical changes in the composition of the pool of unemployed, which is omitted from my analysis.

CPS March supplement (1962-2011) As mentioned above, I extend the analysis from the CPS ORG and monthly data with data from the CPS March supplement, which is available since 1962. Besides the extended sample period, an additional advantage of the March supplement is that it does not rely on matching individuals across different interviews, since data on wages on the previous job are available from the same interview. Thus, it provides a direct test of whether differential attrition by wage group is biasing my results in the analysis with the CPS monthly interview data. A further advantage of the analysis with the CPS March supplement is that it includes any person that had positive earnings during the last calendar year and, thus, includes individuals who have been unemployed for up to 14.5 months compared to 12 months for the monthly data (the interview date is in the middle of the month of March). A weakness, however, of the CPS March supplement is that it is only available once per year and thus does not allow the analysis of monthly transitions between employment and unemployment and vice versa. Moreover, it is not possible to compute an hourly wage over the entire period as for the period before 1976 there is no information on hours worked and thus I use the weekly wage, defined as the total income from wages and salary divided by the number of weeks worked during the previous calendar year. Despite these shortcomings, the CPS March sample allows me to extend the analysis back to 1962 and is a useful robustness check on the analysis with the CPS ORG and monthly data. I use the same sample restrictions and thresholds for trimming in the CPS March supplement, and the sample size is $2,237,705$ out of which 135,708 were unemployed at the time of the March interview.

\subsection{The Cyclicality of the Wage of Job Losers}

Does the composition of the unemployed change over the business cycle? Are there changes in the pool of unemployed by ability? To answer these questions, I use the wage on the previous job as a summary indicator of compositional changes in the pool of unemployed. Panel (a) in Figure 2 plots the average wage of those who lost their job in the previous year, as well as the average wage of those who remained employed. More precisely, it shows the average wage for those who were employed in interview 4 but unempoyed in interview 8 of the CPS, as well as the average wage of those who remained employed. As is apparent from the plot, the average wage of the unemployed is strongly and positively correlated with the 
aggregate unemployment rate (the correlation coefficient is 0.55 ). ${ }^{7,8}$ Panel (a) in Figure 3 shows very similar patterns for the cyclicality of the average wage on previous job, using the CPS March sample over the period 1962-2011. The table further shows that the patterns appear in every single recession since 1962, and the magnitude of the changes is very similar across the two data sources. ${ }^{9}$

One might be concerned about wage compression and argue that the wage differential between those who lose their job and those who remain employed narrows in a recession, simply because overall wage dispersion becomes smaller at the same time. To evaluate this possibility, I attribute an ordinal wage rank to each individual in my data set (the rank in the wage distribution in a given year is defined by lining up all individuals according to their current wage from the lowest to the highest on the unit interval). If wage compression drives the patterns in Panel (a) of Figures 2 and 3, then the average wage rank should show no correlation with the aggregate unemployment rate. However, Panel (b) in the same figures show a very strong correlation of the average wage rank of the unemployed with the aggregate unemployment rate. The correlation coefficient is 0.72 (CPS March data: 0.74), suggesting that wage compression plays no role. In terms of the magnitude, a percentage-point increase in the unemployment rate is, on average, associated with a 1.5 percentage-point increase (CPS March data: 1.2 percentage-point increase) in the average wage rank of the job losers, which represents a substantial shift in the composition of the pool of unemployed.

Panel (c) in Figures 2 and 3 shows the same plot but for the residual of a Mincerstyle regression of the log wage on observable characteristics such as potential experience, educational attainment, gender, marital status, and race, and dummies for state, industry, occupation and year. ${ }^{10}$ The average wage residual is still strongly counter-cyclical for those who lost their job in the previous year, with a correlation with the unemployment rate of 0.58. The magnitude is smaller as a percentage-point increase in the unemployment rate leads to a $0.90 \%$ increase (CPS March data: 0.84\%) in the average residual wage of the unemployed, as compared to a $2.76 \%$ increase (CPS March data: 2.88\%) in the average raw wage in Panel (a). This suggests that both observed and unobserved factors contribute to the compositional changes in the unemployment pool over the business cycle.

To get a better sense of what observable factors drive the compositional changes in the unemployment pool, I regress the detrended series of each component of the predicted wage

\footnotetext{
${ }^{7}$ The unemployment rate is taken from the official tables of the Bureau of Labor Statistics.

${ }^{8}$ One might also note that the compositional changes seem to be slightly leading the unemployment rate. The reason is that - as documented further below - the changes in the pool are driven by the differential cyclicality in job separations, which tend to lead the unemployment rate.

${ }^{9}$ The correlation coefficient of the two series over the period 1980-2008 is 0.84 .

${ }^{10}$ By definition, the average wage residual is zero for each year for the full sample and close to zero for the employed as they represent over $90 \%$ of the full sample.
} 
Figure 2: The average wage from previous year by employment status in CPS ORG files 1980-2008.

(a) Raw wage

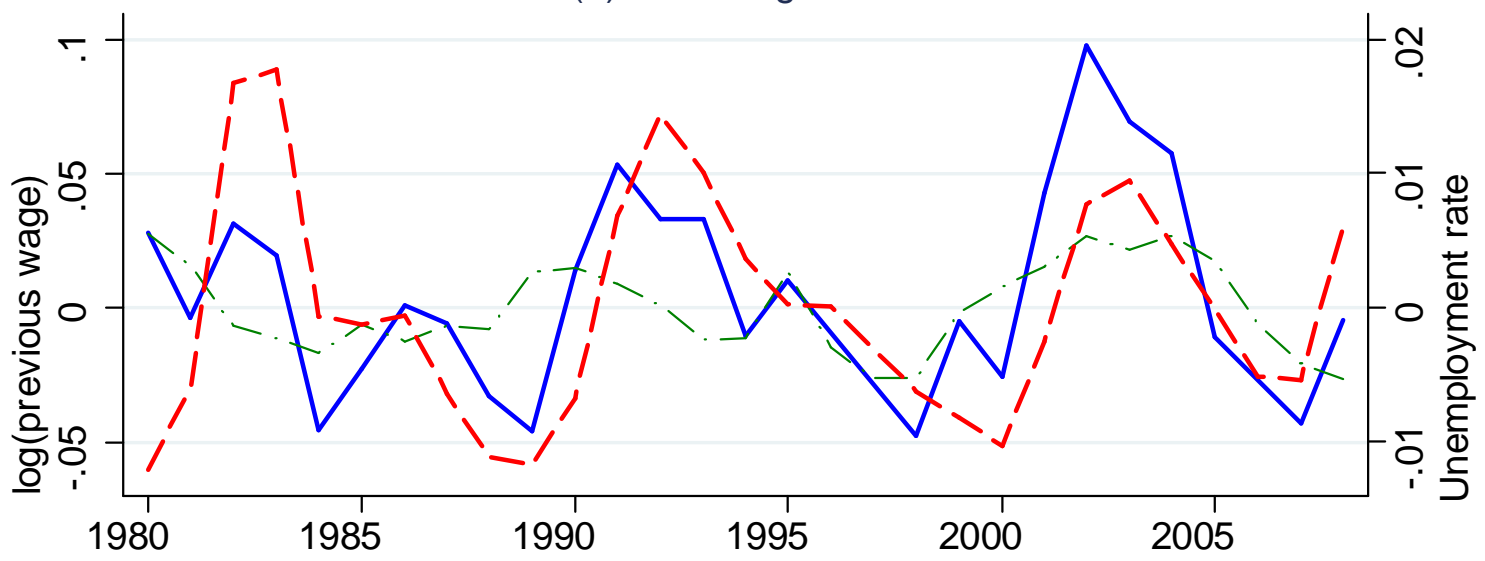

(b) Wage rank

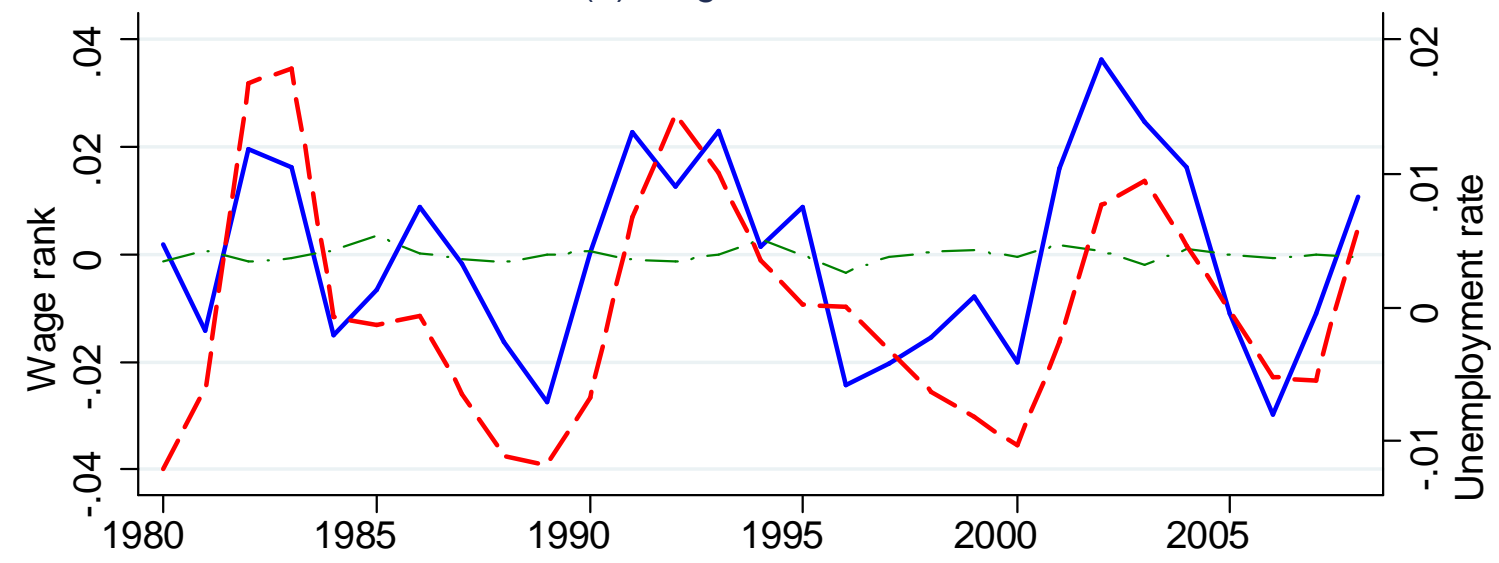

(c) Mincer-residual

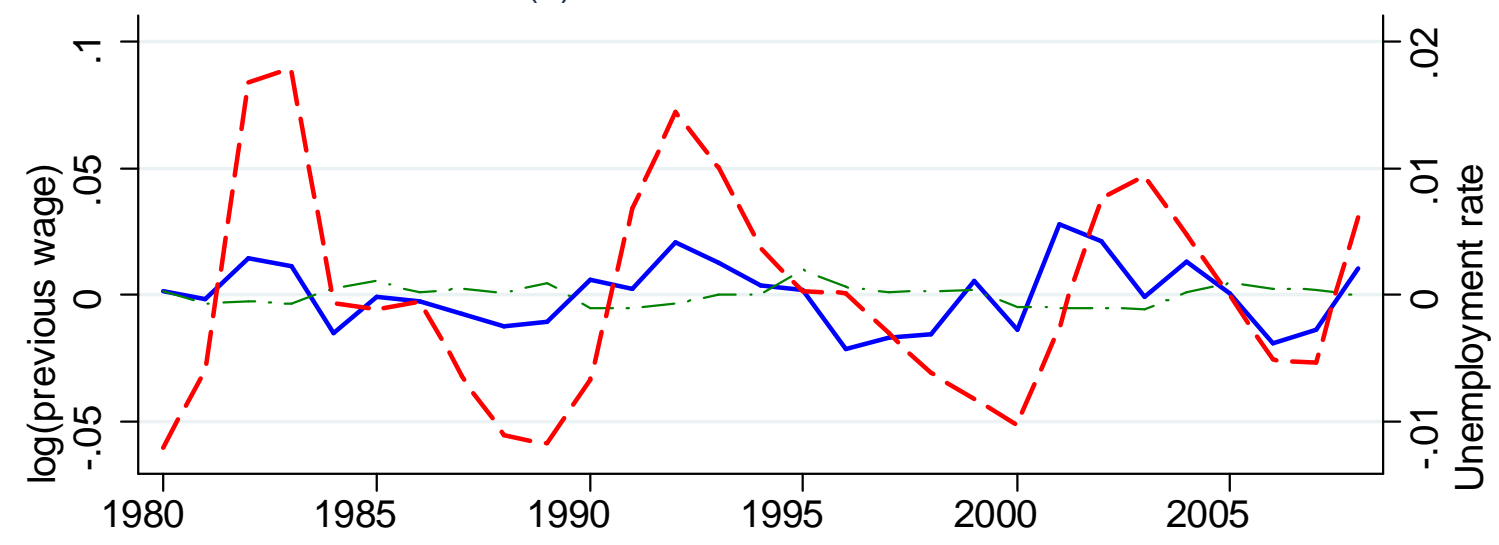

$$
\begin{aligned}
& ---- \text { Unemployment rate } \\
& -\quad \text { Previous w age (Unemployed) } \\
& -\cdot-\cdot \text { Previous w age (Employed) }
\end{aligned}
$$

Note: All series are y early av erages, HP-filtered with smoothing parameter 100. 
Figure 3: The average wage from previous year by employment status in CPS March files 1962-2011.

(a) Raw wage

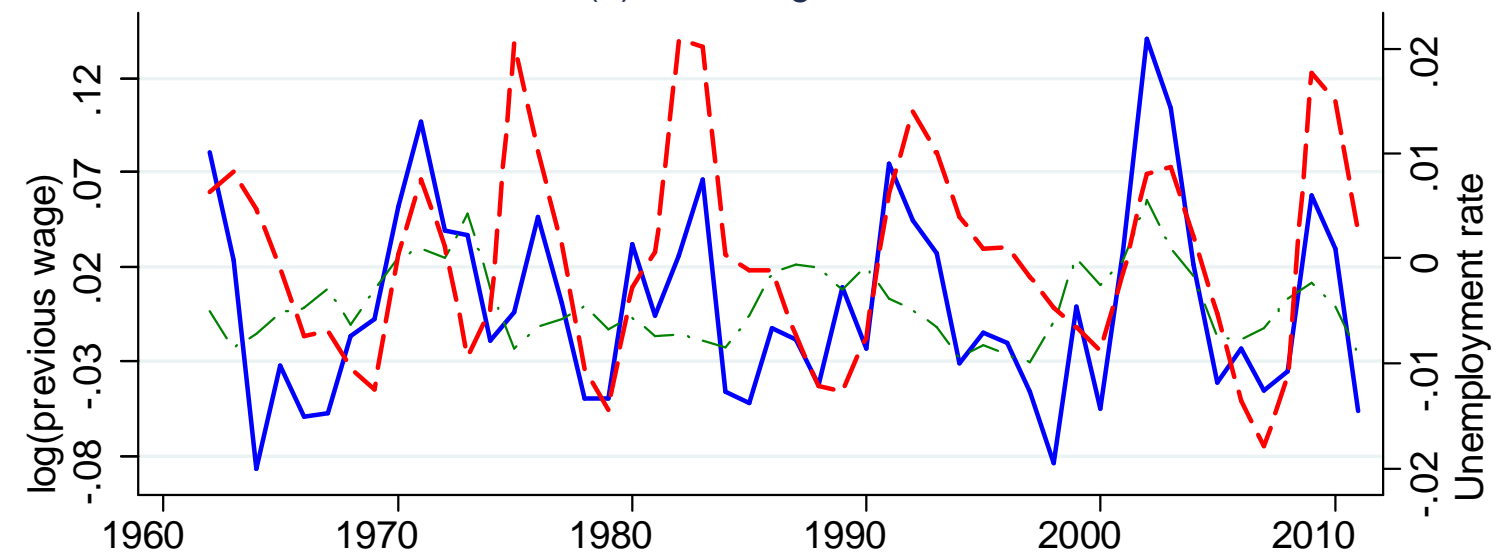

(b) Wage rank

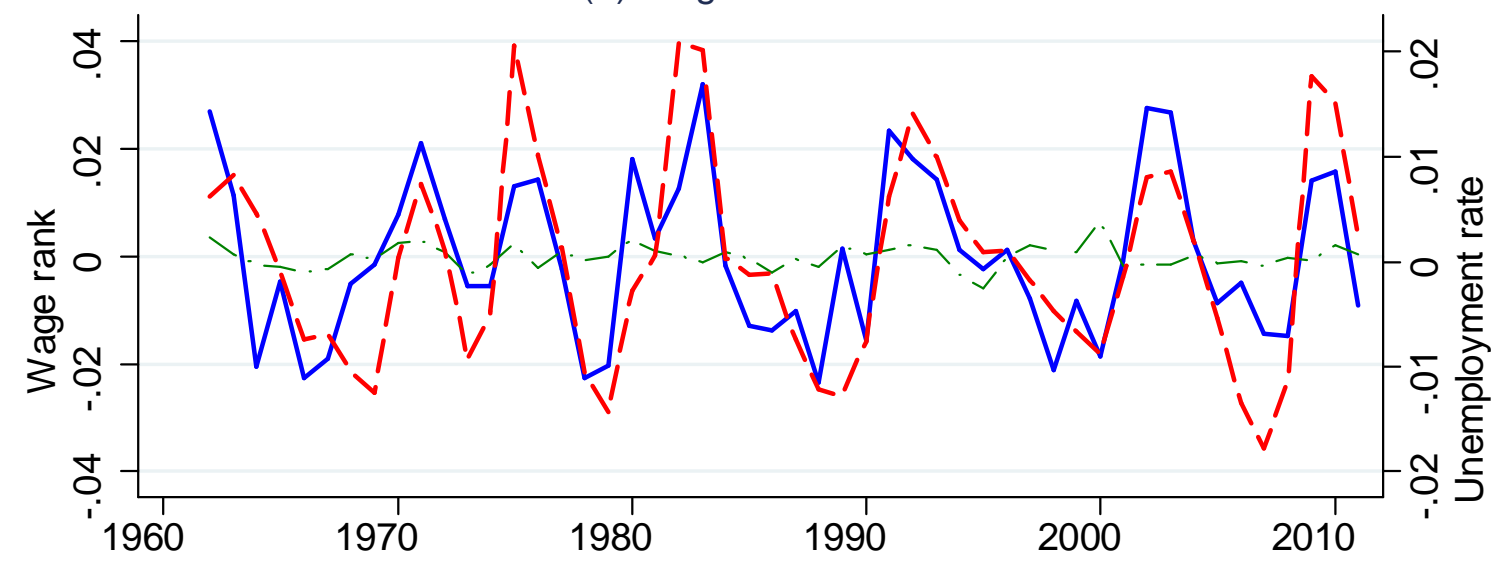

(c) Mincer-residual

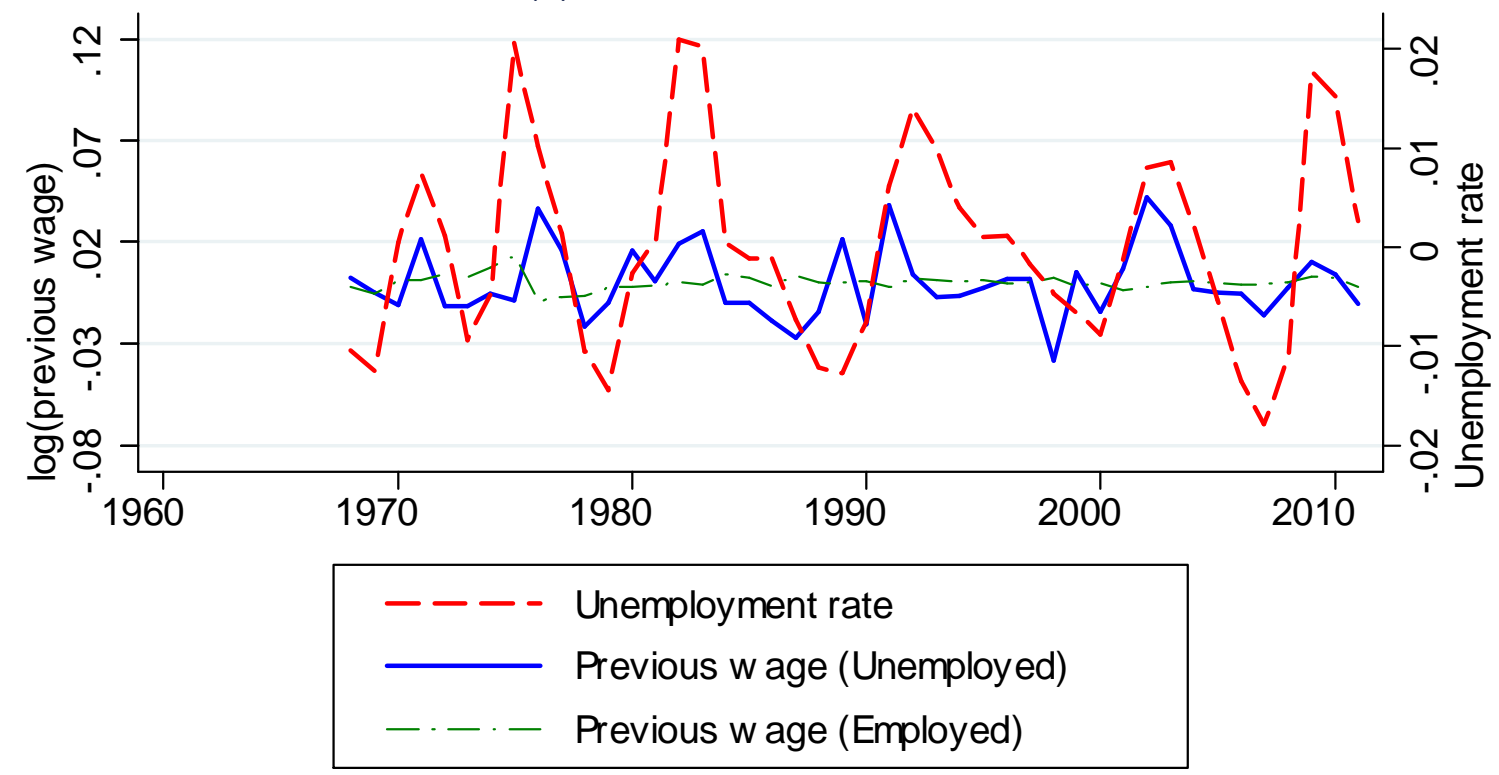

Note: All series are y early av erages, HP-filtered with smoothing parameter 100. 
Table 1. Compositional changes in the pool of unemployed, by predicted and residual wage

\begin{tabular}{|c|c|c|c|c|c|c|c|c|c|c|}
\hline \multirow[b]{3}{*}{ CPS ORG: 1980-2008 } & \multirow[b]{2}{*}{ Raw wage } & \multicolumn{8}{|c|}{ Predicted wage } & \multirow{2}{*}{$\begin{array}{c}\text { Residua } \\
\text { wage }\end{array}$} \\
\hline & & Experience & $\begin{array}{c}\text { Educational } \\
\text { attainment }\end{array}$ & Male & $\begin{array}{l}\text { Marital } \\
\text { status }\end{array}$ & Race & State & Industry & Occupation & \\
\hline & & & & & & & & & & \\
\hline $\begin{array}{l}\text { Cyclicality } \\
\text { (S.e.) }\end{array}$ & $\begin{array}{c}2.76 \\
(0.82)^{* \star *}\end{array}$ & $\begin{array}{c}0.27 \\
(0.10)^{\star \star *}\end{array}$ & $\begin{array}{l}0.10 \\
(0.12)\end{array}$ & $\begin{array}{c}0.17 \\
(0.05)^{\star \star \star}\end{array}$ & $\begin{array}{c}0.22 \\
(0.05)^{\star \star \star *}\end{array}$ & $\begin{array}{c}0.06 \\
(0.02)^{\star *}\end{array}$ & $\begin{array}{c}0.30 \\
(0.15)^{* \star}\end{array}$ & $\begin{array}{c}0.57 \\
(0.14)^{\star \star \star}\end{array}$ & $\begin{array}{c}0.32 \\
(0.20)\end{array}$ & $\begin{array}{c}0.90 \\
(0.16)^{* \star \star}\end{array}$ \\
\hline CPS Marcl & & & & & & & & & & \\
\hline $\begin{array}{l}\text { Cyclicality } \\
\text { (S.e.) }\end{array}$ & $\begin{array}{c}2.88 \\
(0.55)^{*+*+}\end{array}$ & $\begin{array}{c}0.28 \\
(0.08)^{\text {*t+k }}\end{array}$ & $\begin{array}{c}0.17 \\
(0.06)^{*+*+*}\end{array}$ & $\begin{array}{c}0.17 \\
(0.04)^{* * * *}\end{array}$ & $\begin{array}{c}0.34 \\
(0.05)^{*+* k}\end{array}$ & $\begin{array}{c}0.04 \\
(0.02)^{* *}\end{array}$ & $\begin{array}{l}0.13 \\
(0.34)\end{array}$ & $\begin{array}{c}0.73 \\
(0.11)^{\text {tak }}\end{array}$ & $\begin{array}{c}0.42 \\
(0.11)^{\text {tak }}\end{array}$ & $\begin{array}{c}0.84 \\
(0.19)^{*+* *}\end{array}$ \\
\hline
\end{tabular}

Notes: Newey-West corrected standard errors in parentheses; * significant at 10\%; ** significant at $5 \%$; *** significant at $1 \%$; (i) For the predicted and residual wage, the years 1962-67 were not included as no information was available on industry in previous year. All series are yearly averages, HPfiltered with a smoothing parameter of 100 . The cylicality is measured as the coefficient $\beta$ in the regression $\log (x t)=\alpha+\beta \log (U t)+\varepsilon t$, where $x t$ is the average wage from the previous year for those unemployed at time $t$ and $U t$ is the official unemployment rate from the Bureau of Labor Statistic. Note that the coefficients on the predicted and residual wage do not add up exactly to the coefficient on the raw wage because of HP-filtering. Source: The author's estimates with data from the CPS Outgoing Rotation Group files for the years 1979-2008 and the CPS March files for the years 1962-2011.

for those currently unemployed on the detrended aggregate unemployment rate (note that the coefficients on the predicted and residual wage do not add up exactly to the coefficient on the raw wage because of detrending). The results in Table 1 show that, compared to periods of low unemployment, the unemployed in recessions are more experienced, more educated, more likely to be male, more likely to be married, more likely to be white, and more likely to come from industries and occupations that pay high wages. Some of these patterns might be well-known, such as the cyclical changes in the composition of unemployed by gender or industry, but it is striking that all observable components contribute to the changes in the pool of unemployed in the same direction. In terms of the magnitude, the predicted wage from industry and occupation dummies contributes about one third to the total of the compositional changes, whereas the predicted wage of the demographic determinants of the wage and the residual contribute the remaining two thirds. The results are suprisingly similar between the estimates from the CPS ORG files and the CPS March data. This demonstrates that attrition is not causing any major bias in my estimates with the CPS ORG data, as the CPS March data contains backward looking information on wages in the previous year and thus does not rely on matching individuals across survey waves.

I also use official data from the BLS on the number of unemployed by educational attainment, which is available since 1992. This is an important robustness check as it does not exclude the long-term unemployed nor does it exclude those moving into unemployment from out of the labor force. I compute a predicted wage value on educational attainment by computing the share of each group among the unemployed (less than high school, high school degree, some college and college degree) and multiply the share of each group with the estimated coefficient on the dummy for each group in the wage regression. The coefficient in the bivariate regression of the predicted value on educational attainment on the detrended 
aggregate unemployment rate is 0.24 (with a standard error of 0.09 ), which is a little bit higher than the estimates on the predicted value by educational attainment in Table 1, but within the confidence interval. The compositional changes by educational attainment might come as a surprise to some, as the unemployment rate tends to be much more volatile for the low skilled. However, as demonstrated further below, it is the volatility of the log of the unemployment rate, and not the volatility of the level, that matters for the compositional changes in the pool of unemployed.

One thing to keep in mind is that the reported series are HP-filtered such that the mean is zero for both the employed and unemployed over the entire sample period. The mean of the unfiltered series is, however, considerably lower for those who lose their job, as opposed to those who remain employed. This suggests that the unemployed are on average of lower quality, but become more similar to the employed in a recession. To make this point clearer, Panel (a) of Figure 4 shows the densities of the unemployed by percentile of the distribution wages in the previous year. It shows that, in periods of low unemployment, the pool of unemployed is strongly skewed towards the lower part of the distribution of wages, whereas this is much less true in periods of high unemployment. Interestingly, even the share of individuals in the top quartile increases in periods of high unemployment. In fact, in periods of high unemployment, the density looks almost like a uniform density, which suggests that the unemployed in recessions are similar to the average employed person. ${ }^{11}$ The same patterns hold true when looking at the distribution of residual wages (see Panel (b)).

\subsection{The Cyclicality of Separations and Job Findings by Wage Group}

Changes in the composition of the pool of unemployed over the business cycle can arise because of different behavior of inflows into unemployment and/or the different behavior of outflows from unemployment across wage groups. Panels (c) and (d) of Figure 4 show the same patterns for the newly unemployed (i.e., those unemployed for less than one month) as for the pool of unemployed as a whole. The densities look very similar to those in Panels (a) and (b), which suggests that the documented patterns above are driven mainly by the flows into unemployment. To analyse this in more detail, I look at the worker flow data from the CPS ORG sample to determine whether the patterns documented in the previous section are due to job separations or job findings. In particular, I divide the sample in each year into those below and above the median wage and analyze the cyclical behavior of the separation

\footnotetext{
${ }^{11}$ Note that, by definition, the densities follow the uniform distribution for the full sample (i.e., all those employed in the previous year).
} 
Figure 4: Density of unemployed by percentile in the wage distribution from previous year

(a) Unemployed

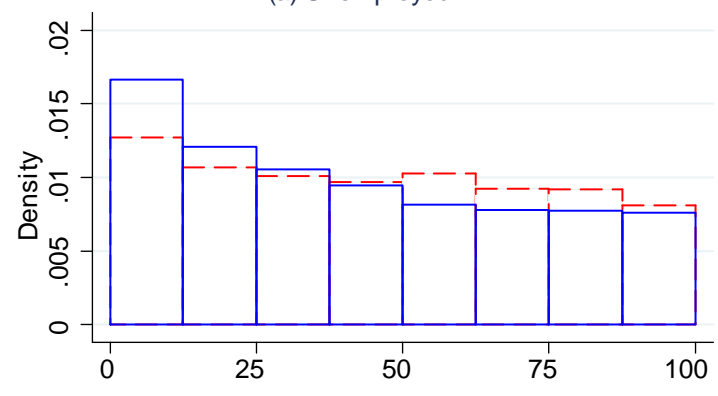

(c) Newly Unemployed

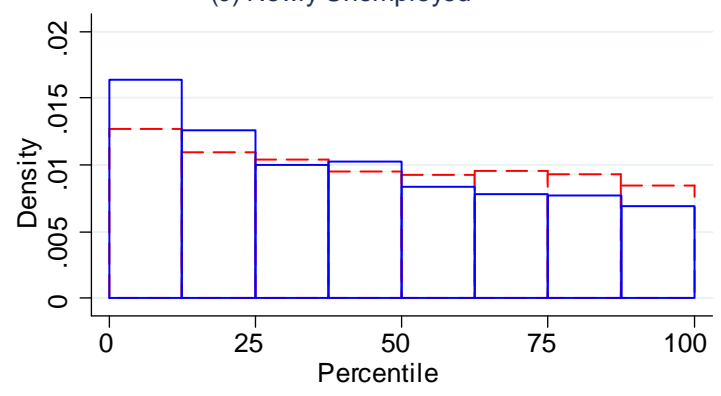

(b) Unemployed (Mincer-residual)

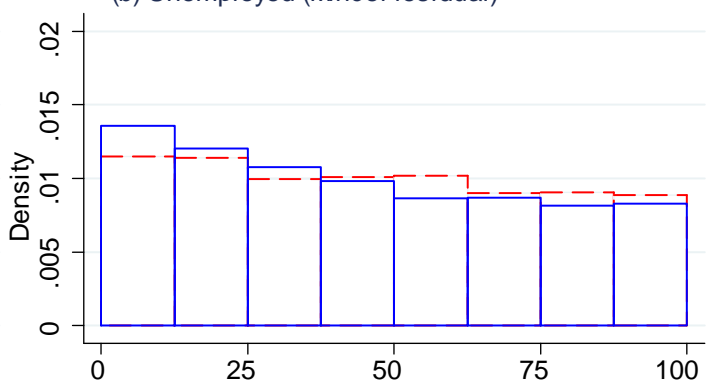

(d) Newly unemployed (Mincer-residual)

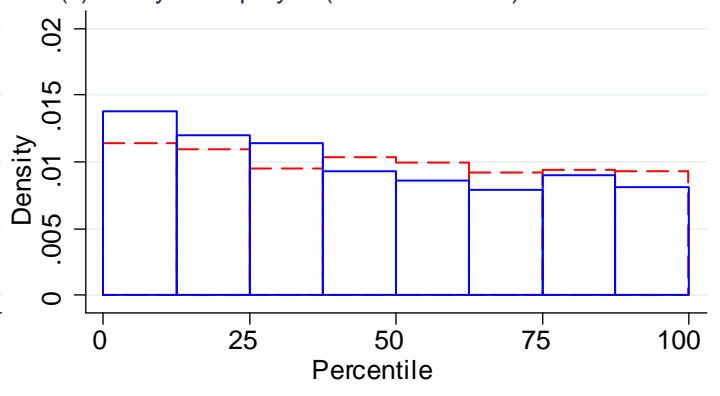

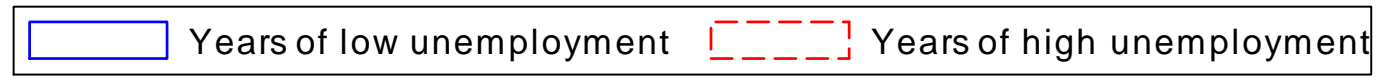

Years of high unemployment = 1982, 1983, 1991, 1992, 1993, 2002, 2003.

Years of low unemployment = 1987, 1988, 1989, 1998, 1999, 2000, 2006, 2007.

and job-finding rate for each of these groups. Job separations and findings are defined as the percentage of those who changed their employment status (from E (employment) to U (unemployment) or from $\mathrm{U}$ to $\mathrm{E}$ ). The groups are divided into below or above the median wage in interview 4 each year, and the transitions are analyzed for subsequent interviews (i.e., monthly transitions between interviews 5 to 6,6 to 7 and 7 to 8 ).

\section{Measurement}

Elsby, Michaels and Solon (2009) show that one can decompose the contributions of separations $(s)$ and job findings $(f)$ to changes in the unemployment rate approximately into

$$
d U_{t} \approx U_{t}^{s s}\left(1-U_{t}^{s s}\right)\left[d \ln s_{t}-d \ln f_{t}\right]
$$

where $U_{t}^{s s}=\frac{s_{t}}{s_{t}+f_{t}}$ is the flow steady state unemployment rate. Now, the share of group $i$ in the pool of unemployed is defined as

$$
\phi_{i t}^{U}=\psi_{i} \frac{U_{i t}}{U_{t}}
$$


where $U_{i t}$ is the unemployment rate of group $i$ at time $t$ and $\psi_{i}$ is the population share for group $i$ (assumed to be constant). Given equations (1) and (2), it can be shown that changes in the share of group $i$ in the pool of unemployed can be decomposed into

$$
d \phi_{i t}^{U} \approx \phi_{i t}^{U}\left(\begin{array}{c}
\left(1-U_{i t}^{s s}\right)\left[d \ln s_{i t}-d \ln f_{i t}\right] \\
-\left(1-U_{t}^{s s}\right)\left[d \ln s_{t}-d \ln f_{t}\right]
\end{array}\right)
$$

which implies that changes in the share of group $i$ are related to changes in the $\log$ of the separation and job-finding rate of group $i$ relative to the average. More importantly, since $\left(1-U_{i t}^{s s}\right)$ is very similar across groups, one can directly conclude from the magnitude of the changes in the log separation and job-finding rates which margins are more important for the changes in the composition of the pool. To understand how separations and job findings relate to cyclical changes in the unemployment rate, one thus has to relate the changes in the log of the separation and job-finding rate to the aggregate unemployment rate (or other cyclical indicators). For this reason, I run the following regressions:

$$
\ln x_{i t}=\alpha_{i}^{x}+\beta_{i}^{x} \ln U_{t}+\varepsilon_{i t}^{x},
$$

where $x_{i t}$ stands for $s_{i t}$ (separation rate), $f_{i t}$ (job-finding rate) or $U_{i t}$ (unemployment rate) for group $i$ at time $t$ and the measure of cyclicality is the percent increase in $x_{i t}$ in response to a $1 \%$ increase in the aggregate unemployment rate (the coefficient $\beta_{i}^{x}$ ). All series are monthly, seasonally adjusted, and detrended with an HP-filter with smoothing parameter $900,000 .^{12}$

\section{Results}

Table 2 summarizes the main results for different groups in terms of the average as well as the cyclicality of separation and job-finding rates. The first two columns split the sample into those below and above the median wage. Columns 3 and 4 report the results for those below and above the median residual wage.

Not surprisingly, separations are on average lower for high-wage workers than for lowwage workers. The main new result, however, is that the cyclicality of separations is almost twice as large for individuals with high wages compared to those below the median. ${ }^{13}$ The

\footnotetext{
${ }^{12}$ I follow Bils, Chang and Kim (2009) who detrend the monthly time series with an HP-filter with smoothing parameter 900,000. This is the equivalent of Shimer's (2005) detrending choice of a smoothing parameter of 100,000 for a quarterly time series. The published version of Bils, Chang and Kim (2012) does no longer follow this detrending choice. Appendix Tables A.1-A.3 show that my results are robust to other detrending methods, and in particular to HP-filtering with a smoothing parameter of 14,400 .

${ }^{13} \mathrm{My}$ results are also consistent with Fujita and Ramey's (2009) analysis who show that - using CPS worker flow data from 1976 to 2005 - that separations account for approximately $50 \%$ of the overall volatility
} 
Table 2. The cyclicality of separation and job-finding rates, by wage group

\begin{tabular}{|c|c|c|c|c|c|}
\hline & & \multicolumn{2}{|c|}{$\underline{\text { Log(hourly wage) }}$} & \multicolumn{2}{|c|}{ Mincer residual } \\
\hline & & low & high & low & high \\
\hline \multirow[t]{2}{*}{ Separations } & Average & 0.012 & 0.007 & 0.010 & 0.008 \\
\hline & $\begin{array}{l}\text { Cyclicality } \\
\text { (s.e.) }\end{array}$ & $\begin{array}{c}\mathbf{0 . 4 0} \\
(0.078)^{* * *}\end{array}$ & $\begin{array}{c}\mathbf{0 . 7 4} \\
(0.096)^{\star * k}\end{array}$ & $\begin{array}{c}\mathbf{0 . 4 3} \\
(0.063)^{* \star * *}\end{array}$ & $\begin{array}{c}\mathbf{0 . 6 8} \\
(0.077)^{*+*}\end{array}$ \\
\hline \multirow[t]{2}{*}{ Job findings } & Average & 0.303 & 0.283 & 0.292 & 0.296 \\
\hline & $\begin{array}{l}\text { Cyclicality } \\
\text { (s.e.) }\end{array}$ & $\begin{array}{c}\mathbf{- 0 . 5 6} \\
(0.054)^{\star \star \star}\end{array}$ & $\begin{array}{c}\mathbf{- 0 . 7 0} \\
(0.072)^{\star \star *}\end{array}$ & $\begin{array}{c}\mathbf{- 0 . 6 5} \\
(0.059)^{\star \star \star *}\end{array}$ & $\begin{array}{c}\mathbf{- 0 . 6 0} \\
(0.064)^{* k *}\end{array}$ \\
\hline \multirow[t]{2}{*}{ Unemployment } & Average & 0.037 & 0.024 & 0.033 & 0.026 \\
\hline & $\begin{array}{l}\text { Cyclicality } \\
\text { (s.e.) }\end{array}$ & $\begin{array}{c}\mathbf{0 . 8 1} \\
(0.024)^{\star \star \star}\end{array}$ & $\begin{array}{c}1.25 \\
(0.030)^{* \star *}\end{array}$ & $\begin{array}{c}\mathbf{0 . 8 9} \\
(0.025)^{*+*}\end{array}$ & $\begin{array}{c}\mathbf{1 . 1 3} \\
(0.031)^{* \star \star}\end{array}$ \\
\hline \multicolumn{6}{|c|}{$\begin{array}{l}\text { Notes: Newey-West corrected standard errors in parentheses; * significant at } 10 \% ; * * \text { significant at } 5 \% \text {; ** } \\
\text { significant at } 1 \% \text {. All series are HP-filtered with a smoothing parameter of } 900,000 \text {. The cylicality is measured as } \\
\text { the coefficient } \beta \text { in the regression } \log (\mathrm{xit})=\alpha+\beta \log (\mathrm{Ut})+\varepsilon i t \text {, where xit is the separation, job-finding or } \\
\text { unemployment rate of group i at time } t \text { and } \mathrm{Ut} \text { is the sample unemployment rate. Similar to Bils, Chang and Kim } \\
\text { (2009), I instrument the sample unemployment rate with the official unemployment rate because of measurement } \\
\text { error. Sample size: } 322 \text { monthly observations. Source: The author's estimates with data from the CPS Outgoing } \\
\text { Rotation Group and CPS monthly files for the years } 1979-2008 \text {. }\end{array}$} \\
\hline
\end{tabular}

difference is somewhat smaller when looking at the cyclicality of separations for those below and above the median residual wage: The ratio of $\frac{\beta_{\text {low }}^{\text {sep }}}{\beta_{h i g h}^{\circ e q}}$ is 0.63 compared to 0.54 for the cyclicality with the raw wage measure.

Job-finding rates are of similar size, on average, for both groups, and also their cyclicality is very similar across groups: The cyclicality of job findings is slightly more cyclical for those above the median wage, but the pattern reverses for the residuals and the differences are not statistically significant. Overall, I conclude that changes in the composition of the pool in terms of the previous wage are driven:

1. almost entirely by the different cyclicality of separations as opposed to job findings and

2. by observable as well as unobservable characteristics of the unemployed.

These facts are robust across a large range of different specifications and sample selection criteria. Appendix Tables A.1, A.2 and A.3 show very similar results for different sample restrictions (age 25-54, men only, full-time workers only, college educated only, excluding manufacturing and construction) and different filters. The patterns are also similar when one includes those OLF (out of the labor force) or excludes those on temporary layoff. of unemployment. Using Elsby et al.'s decomposition in equation 1, separations account for $42 \%$ of the volatility of unemployment for the low-wage group and for $51 \%$ for the high-wage group. 
Finally, I use Fujita and Ramey's (2009) adjustment for time aggregation bias and find that the differences in the cyclicality of separations are even stronger for those below and above the median wage. Table A.4 also shows the baseline results but splitting the quartiles of the wage distribution each year instead of below and above the median. The results are very similar and show that separations are most cyclical in the top quartile of the distribution of the hourly wages, suggesting that the proportion of unemployed workers coming from the top quartile increases in a recession. ${ }^{14}$

\section{Job-to-Job Transitions and Discouragement}

The measure of job separation above does not include job-to-job transitions (in other words, job separations that do not result in an intervening spell of unemployment), and thus one possible explanation for the patterns documented above could be that during good times high-wage workers transition directly from job to job, but during bad times they have to go through a spell of unemployment to find new employment. The original CPS did not ask respondents about job switches, but fortunately with the redesign of the CPS in 1994, it became possible to identify those who switched jobs between two monthly interviews (see Fallick and Fleischman, 2004, for details). Table 3 shows the average and the cyclicality of job-to-job transitions for the same groups as in Table 2. As in Fallick and Fleischman, the monthly job-to-job transitions are about twice as large as the flow from E to U. The jobto-job transitions are procyclical, but less so for individuals with high wages. In particular, the cyclicality for those with high residual wages is -0.06 , compared to -0.23 for those with low residual wages. This evidence does not support the view that the high cyclicality of separations for high-wage workers is driven by the fact that direct job-to-job transitions decrease strongly during recessions for this group. On the contrary, it appears that job-tojob transitions decrease more for low-wage workers in recessions and thus one would expect separations into unemployment to be more cyclical for the low-wage group. In other words, on-the-job search by high-wage individuals is unlikely to explain the cyclical patterns in the pool of unemployed.

Another possible explanation of the shifts in the pool of unemployed workers towards high-wage workers could be related to worker discouragement. If low-wage workers get discouraged faster in recessions and leave the pool of unemployed towards out of the labor force, then the pool of unemployed should shift towards high-wage workers. Table 3 shows the average as well as the cyclicality of transitions from unemployed (U) to out of the labor force $(\mathrm{OLF})$. On average, low-wage workers tend to leave unemployment more frequently

\footnotetext{
${ }^{14}$ When looking at the cyclicality of separations in the distribution of the residual wages in Panel B of Table A.4, the cyclicality of separation is highest in the third quartile. However, the cyclicality of separations in the top quartile is still considerably higher than in the first and second quartile.
} 
Table 3. The cyclicality of job-to-job transitions and movements from unemployment (U) to out of the labor force (OLF), by wage group

\begin{tabular}{|c|c|c|c|c|c|}
\hline & \multicolumn{2}{|c|}{$\underline{\text { Log(hourly wage) }}$} & \multicolumn{2}{|c|}{$\underline{\text { Mincer residual }}$} \\
\hline & & low & high & low & high \\
\hline \multirow{3}{*}{$\begin{array}{l}\text { Job-to-job transitions } \\
\text { (1994-2008 only) }\end{array}$} & Average & 0.023 & 0.018 & 0.022 & 0.019 \\
\hline & Cyclicality & -0.17 & -0.12 & -0.23 & -0.06 \\
\hline & (s.e.) & $(0.055)^{\star \star \star *}$ & $(0.068)^{*}$ & $(0.059)^{* \hbar *}$ & $(0.073)$ \\
\hline \multirow[t]{3}{*}{ Transitions from $U$ to $C$} & Average & 0.140 & 0.081 & 0.124 & 0.101 \\
\hline & Cyclicality & -0.46 & -0.44 & -0.51 & -0.48 \\
\hline & (s.e.) & $(0.077)^{\star \star \star \star}$ & $(0.173)^{* *}$ & $(0.074)^{\star \star \star *}$ & $(0.159)^{\star \star \star}$ \\
\hline
\end{tabular}

Notes: Newey-West corrected standard errors in parentheses; * significant at $10 \%$; ** significant at $5 \%$; ***

significant at $1 \%$. See notes in Table 1 for further details. Source: The author's estimates with data from the CPS

Outgoing Rotation Group and CPS monthly files for the years 1979-2008.

towards OLF. However, the cyclicality between the two groups is almost identical, which suggests that transitions between $U$ and OLF cannot account for compositional changes in the pool of unemployed documented above.

In summary, the data strongly suggests that the unemployment pool shifts towards highwage individuals in recessions, and this shift is mainly due to job separations.

\subsection{Relation to Previous Research}

Bils, Chang and Kim (2012) find similar patterns in the data for low-wage vs. high-wage workers from the Survey of Income and Program Participation (SIPP) for the years 19832003, but they focus their attention on the cyclical nature of employment for these groups and pay little attention to the question of cyclical changes in the composition of the pool of unemployed. More precisely, they split their sample into four groups - by low or high hours and by low or high wages - and report the cyclicality of separations, hirings, employment and hours worked. Averaging the cyclicality of separations for the wage groups, one finds that the ratio of the cyclicality of separations between the low- and high-wage group is about 0.55, similar to my estimates in the CPS data.

Solon, Barsky and Parker (1994) show that there is a substantial composition bias when looking at the cyclicality of aggregate real wages. The employed become more skilled during recessions, leading the researcher to underestimate the cyclicality of real wages when looking at aggregate wage data. This evidence seems to be in contrast with the facts presented above, because it suggests that the proportion of high-wage workers among the employed increases in recessions. However, their evidence relies on the composition bias in the aggregate hourly wage, which is a weighted average by hours. Therefore, the composition bias could be driven 
either by a higher cyclicality of hours for the low skilled (the intensive margin) or a higher cyclicality of employment for the low skilled (the extensive margin). In fact, Hines, Hoynes and Krueger (2001) show that Solon, Barsky and Parker's results rely on the weighting of aggregate real wages by hours worked. They demonstrate that with unweighted wage data, composition bias has almost no effect on the cyclicality of real wages, suggesting that it is not the composition of the employed that changes over the business cycle but rather the hours worked by different skill groups.

Another important observation is that the pool of unemployed and the pool of employed do not necessarily have to shift in the same direction if the pools differ in the average quality. Specifically, since the typical unemployed is of lower ability than the typical employed, a transition of a worker from the lower part of the distribution of the pool of employed to the upper part of the distribution of the pool of unemployed can make both pools better off. More formally, one can approximate the relationship between changes in the share of group $i$ in the pool of unemployed $\left(d \phi_{i t}^{U}\right)$ and changes in the share of group $i$ in the pool of employed $\left(d \phi_{i t}^{E}\right)$ as follows ${ }^{15}$ :

$$
d \phi_{i t}^{E} \approx \phi_{i t}^{E}\left[-2 U_{t} d \phi_{i t}^{U}+d U_{t}\left(1-2 \phi_{i t}^{U}\right)\right]
$$

which implies that if the shares of the two groups are the same $\left(\phi_{i t}^{U}=0.5\right)$, then the pools must sort in opposite directions. However, in reality the share of high-wage workers among the unemployed is higher $\left(\phi_{\text {high }, t}^{U}=0.39\right.$ in the CPS sample) and thus shifts do not necessarily go in the opposite direction. Moreover, changes in the group share among the unemployed lead to much smaller changes in the group share among the employed, because the group of unemployed is so much smaller compared to the group of employed. In fact, one can compute the response of the share of the high-wage types from the estimates in Table 2, and then use the formula in equation (5) to compute the implied change in the share in the pool of employed. The results are as follows:

$$
\begin{aligned}
& \frac{d \phi_{\text {high,t }}^{U}}{d U_{t}} \approx 3.2 \\
& \frac{d \phi_{\text {high,t }}^{E}}{d U_{t}} \approx 0.012,
\end{aligned}
$$

which says that the share of the high-wage types amongh the unemployed increases by more than three percentage points in response to a one percentage-point increase in the aggregate unemployment rate. These results also imply that the pool of employed shifts in the same direction, but the shift is much smaller in magnitude than for the pool of unemployed and close to zero: A percentage-point increase in the unemployment rate increases the share of

\footnotetext{
${ }^{15}$ See Appendix B for details.
} 
the high-wage types by 0.012 percentage points. To conclude, the large shifts in recessions towards high-wage workers in the pool of unemployed documented above are consistent with small shifts towards high-wage workers in the pool of employed.

\section{Model}

In this and the following section, I evaluate a number of theories that can potentially explain the compositional shifts in the pool of unemployed over the U.S. business cycle. I start with an extension of the standard search-matching model ${ }^{16}$ to worker heterogeneity and find that it has difficulties in replicating the facts summarized above. Then, I consider further extensions of this baseline model that can potentially account for the documented facts.

In the baseline model, there are two types of workers (indexed by $i$ ) who differ in their market productivity $a_{i}$ and potentially other parameters. Similar to Bils, Chang and Kim (2012), I assume worker ability to be observable to the potential employer and thus firms can direct their search to a particular worker type. ${ }^{17}$ More precisely, there is a continuum of workers of each type and a continuum of firms, which are matched according to the matching function:

$$
M_{i}=\kappa u_{i}^{\eta} v_{i}^{1-\eta}
$$

The job finding probability is $p\left(\theta_{i}\right)=\frac{M_{i}}{u_{i}}$ and the hiring rate $q\left(\theta_{i}\right)=\frac{M_{i}}{v_{i}}$.

Match productivity is defined as $z x a_{i}$ where $z$ is aggregate productivity, $x$ match-specific productivity and $a_{i}$ worker-specific productivity. Match-specific productivity is assumed to follow an $\mathrm{AR}(1)$ process as discussed below in the calibration strategy. I assume that all matches start at the median match productivity $\bar{x}$.

Let us proceed to describe the value functions of workers and firms. The value function of an unemployed worker of type $i$ is:

$$
U_{i}(z)=b_{i}+\beta E\left[\left(1-f\left(\theta_{i}\right)\right) U_{i}\left(z^{\prime}\right)+f\left(\theta_{i}\right) W_{i}\left(z^{\prime}, \bar{x}\right) \mid z\right]
$$

where aggregate productivity $z$ is the aggregate state. The value of being unemployed depends on the unemployment benefit, $b_{i}$, which potentially depends on worker type, and the discounted value of remaining unemployed in the next period or having a job with the value $W_{i}\left(z^{\prime}, \bar{x}\right)$.

\footnotetext{
${ }^{16}$ The main reference is Pissarides (2000). I deviate from his model by allowing match-specific productivity shocks to be correlated across time.

${ }^{17}$ Model Appendix C1 discusses a model where worker ability is unobservable by the employer and thus search on the firm is non-directed. The results of the model with non-directed search are similar to those of the model with directed search; in particular, the assumption of non-directed search has little impact on the cyclicality of separations for different ability groups.
} 
The value function of an employed worker is:

$$
W_{i}(z, x)=w_{i}(z, x)+\beta E\left[\max \left\{W_{i}\left(z^{\prime}, x^{\prime}\right), U_{i}\left(z^{\prime}\right)\right\} \mid z, x\right],
$$

which depends on the utility from the current wage and the discounted future expected value. Whenever the value of the job $W_{i}$ is lower than the value of being unemployed $U_{i}$, the worker will separate and thus receive the value $U_{i}\left(z^{\prime}\right)$ in the next period.

The value of posting a vacancy for a firm is:

$$
V_{i}(z)=-c_{i}+\beta E\left[\left(1-q\left(\theta_{i}\right)\right) V_{i}\left(z^{\prime}\right)+q\left(\theta_{i}\right) J_{i}(z, \bar{x}) \mid z\right],
$$

which depends on the vacancy posting cost $c_{i}$ and the discounted future expected value. Note that $q\left(\theta_{i}\right)$ is the firm's hiring rate, the rate at which it fills a posted vacancy.

The value of a filled vacancy is:

$$
J_{i}(z, x)=z x a_{i}-w_{i}(z, x)+\beta E\left[\max \left\{J_{i}\left(z^{\prime}, x^{\prime}\right), V_{i}\left(z^{\prime}\right)\right\} \mid z, x\right],
$$

which depends on the cash flow (productivity minus the wage) and the discounted future expected value. Note that the firm will fire the worker whenever the value of the filled vacancy is lower than the value of posting a vacancy.

Wages are determined by standard Nash-bargaining and split the joint surplus from the employment relationship according to the Nash-bargaining solution:

$$
\left[W_{i}(z, x)-U_{i}(z)\right]=\frac{\alpha}{1-\alpha}\left[J_{i}(z, x)-V_{i}(z)\right],
$$

where $\alpha$ is the bargaining share of the worker.

Firm-worker matches are dissolved whenever the joint surplus from the relationship $\left(S_{i}(z, x)=W_{i}(z, x)-U_{i}(z)+J_{i}(z, x)-V_{i}(z)\right)$ is smaller than zero, which implies that the reservation match productivity $R_{i}(z)$, i.e., the level of match-specific productivity $x$ below which the employment relationship is dissolved, satisfies:

$$
S_{i}\left(z, R_{i}(z)\right)=0 .
$$

I refer to (12) as the efficient-separation condition. Separations are always in the interest of both parties and never unilateral (thus efficient).

A directed search equilibrium is defined as the reservation match productivity $R_{i}(z)$, the wage schedules $w_{i}(z, x)$, the labor market tightness $\theta_{i}(z)$ and the value functions $U_{i}(z)$, $W_{i}(z, x), V_{i}(z)$ and $J_{i}(z, x)$ that satisfy: 1 . the Nash-bargaining solution (11), 2. the efficient- 
separation condition (12), 3. the zero-profit condition: $V_{i}(z)=0$ and 4 . the value functions (7), (8), (9) and (10).

\subsection{Calibration}

The main parameters of the model are calibrated to standard values in the literature. The following tabulation summarizes the calibration strategy.

Tabulation of the calibrated values of the main parameters of the model:

\begin{tabular}{lll}
\hline Parameter & Parameter name & Source/Target \\
\hline$\beta=0.9966$ & Discount factor & $\mathrm{r}=4.17 \%$ \\
$\mathrm{c}_{\text {high }}=0.63 ; \mathrm{c}_{\mathrm{low}}=0.24{ }^{(1)}$ & Vacancy-posting cost & Monthly job-finding rate $=0.3$ \\
$\eta=0.5$ & Elasticity of matching function & Micro studies \\
$\kappa=0.3$ & Matching efficiency & $\theta=1$ \\
$\alpha=0.5$ & Worker's bargaining power & Hosios condition \\
$\mathrm{b}=0.6$ & Unemployment benefit & $\begin{array}{l}\text { Shimer (2005); Hagedorn and } \\
\text { Manovskii (2008) }\end{array}$ \\
$\ln \left(\mathrm{x}_{\mathrm{t}+1}\right)=0.98 \ln \left(\mathrm{x}_{\mathrm{t}}\right)+\varepsilon_{\mathrm{t}}$ & Match-specific productivity & Bils, Chang and Kim (2009) \\
$\sigma_{\varepsilon}=0.03$ & Std of match-specific shocks & Monthly separation rate $=0.01$ \\
$\mathrm{z}_{\mathrm{g}}=1.02 ; \mathrm{z}_{\mathrm{b}}=0.98$ & Aggregate state & Shimer (2005) \\
$\pi_{\mathrm{gb}}=\pi_{\mathrm{bg}}=1 / 24$ & Transition probabilities & Duration of recession = 2 years \\
$\mathrm{a}_{\text {high }} / \mathrm{a}_{\mathrm{low}}=1.2 / 0.8$ & Ratio of worker productivity & Wage dispersion in CPS data \\
\hline
\end{tabular}

(1) The vacancy posting costs are chosen to match a month ly job-fin ding rate of 0.3 . Therefore, the values change for altemative calibrations of the model.

The parameters are chosen to be the same for both groups of workers unless otherwise noted. The vacancy posting $\operatorname{cost} c_{i}$ is calibrated internally to match a monthly job-finding rate of 0.3 for both groups (as in the CPS data). The elasticity of the matching function $\eta$ is in accordance with estimates from micro studies and is set to 0.5. The matching efficiency $\kappa$ is a free parameter in the model and chosen such that $\theta=1$ in steady state. The worker's bargaining power is set equal to the elasticity of the matching function in order to satisfy the Hosios condition. The log of match productivity is assumed to follow an $\operatorname{AR}(1)$ process with the autocorrelation coefficient 0.98 . The standard deviation of match productivity shocks is set to match an average monthly separation rate of 0.01 , as in the 
CPS data. I discretize the state space in terms of match productivities $x$ with Tauchen's (1986) algorithm. Aggregate productivity $z$ is assumed to take on two values, set to match a standard deviation of aggregate labor productivity of 0.02, as reported by Shimer (2005). The productivitiy parameters $a_{l o w}$ and $a_{h i g h}$ are assumed to be 0.8 and 1.2. In the CPS data the ratio of the wage of the group below and above the median wage is around 0.4. Thus, the assumption of $a_{\text {high }} / a_{\text {low }}=1.2 / 0.8$ is a conservative estimate of differences in worker productivites. The unemployment benefit is assumed to be constant and equal to 0.6 (somewhere in between the extreme assumptions of Shimer (2005) and Hagedorn and Manovskii (2008)). The assumption of a constant benefit by worker type implies that, at the median match productivity $\bar{x}=1$, the ratio of benefits over worker productivity is 0.75 for the low types and 0.5 for the high types. This strategy is motived by two main observations: First, wages are generally replaced only up to a specified limit. In the U.S., the maximum unemployment benefit is binding for approximately 35\% of the unemployed workers (see Krueger and Meyer, 2002). Second, the parameter $b$ should also capture the utility derived from additional leisure during unemployment as well as consumption provided by additional home production, which is likely to be less than perfectly correlated with market ability, $a$. For these reasons, the replacement rates should be higher for the low-ability group.

\subsection{Results}

Table 4 reports results for the baseline calibration. The same filtering methods as for the empirical results from the CPS are applied to the simulated time series. Evidently, the model generates higher average separation rates for low-ability workers. However, the model does not do well in capturing the cyclicality of separations as it generates a higher, not lower, cyclicality of separations for the low-ability types.

The reason for this failure is related to the cyclical behavior of the worker's outside option. The efficient-separation equation (12), rewritten for convenience, is

$$
W_{i}\left(z, R_{i}(z)\right)+J_{i}\left(z, R_{i}(z)\right)=U_{i}(z)
$$

where the left-hand side is the value of the match and the right-hand side is the value of the outside option. When aggregate labor productivity increases, the value of the match increases proportionally, whereas the value of being unemployed increases by less than onefor-one because $b$ is constant over the business cycle. Therefore, staying employed becomes more attractive as aggregate productivity increases and thus $R_{i}$ decreases. For workers with low ability, the outside option fluctuates less as the constant term of $U_{i}$ (the unemployment benefit $b$ ) is large relative to the non-constant term (the expected value in the next period) 
Table 4. Bas eline model: The cyclicality of separation and job-finding rates, by ability type

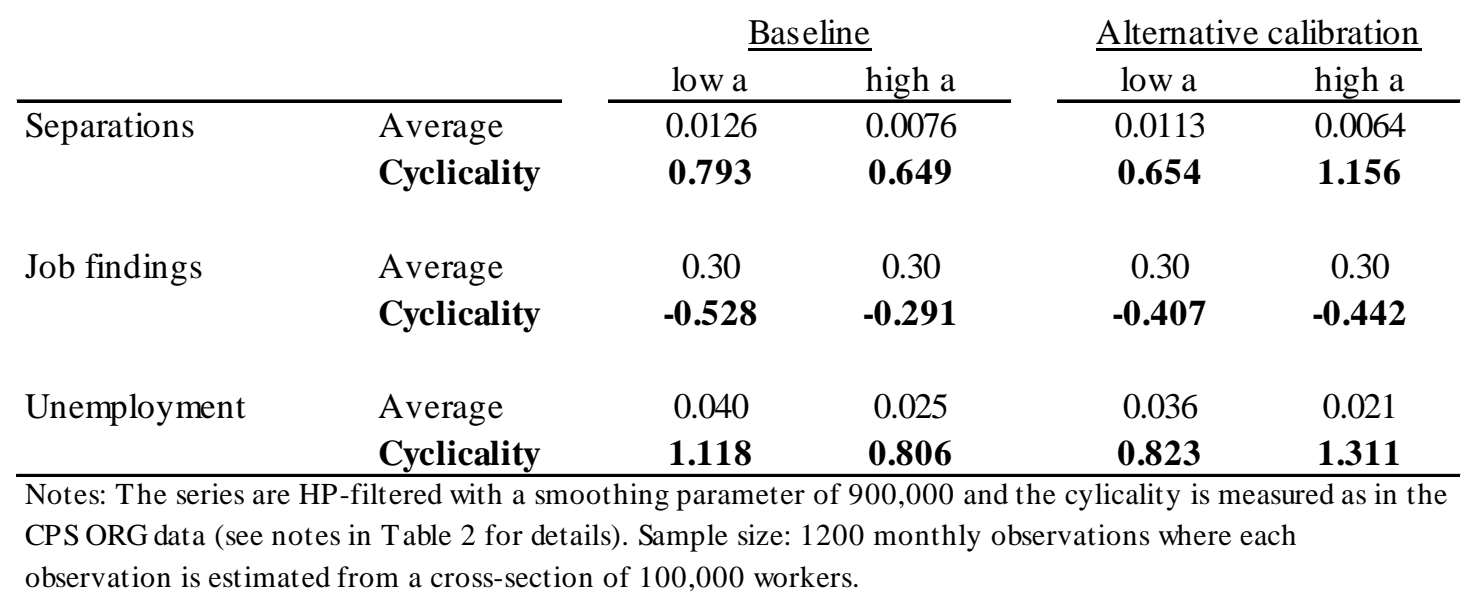

and thus $R_{i}$ changes more in response to an aggregate productivity shock. For this reason, separations are more cyclical for low-ability workers.

Table 4 also shows the results for an alternative calibration strategy where I assume that the unemployment benefit is proportional to worker ability $\left(b_{i}=b a_{i}\right)$ and the variance of match productivity is higher for low-ability workers ${ }^{18}$. More precisely, I assume that $\sigma_{\varepsilon}$ is twice as large for the low-ability group $\left(\sigma_{\varepsilon}^{h i g h}=0.02 ; \sigma_{\varepsilon}^{\text {low }}=0.04\right)$. In line with the data, this model generates higher average separation rates for low-ability workers. More importantly, this model also generates a higher cyclicality of separation rates for high-ability workers. The reason is that the density of matches with $x=R_{i}$ is higher for the low-variance (high-ability) group, and thus, changes in the reservation match productivity translate into larger changes in the separation rate. ${ }^{19}$

This second calibration strategy generates both lower separations and a higher cyclicality of separations for the high-wage group. However, it is unclear why the variance of matchspecific productivity shocks should be higher for low-ability workers. One way of evaluating whether high-wage workers have a lower variance of match productivity shocks is to look at the yearly wage changes between the two outgoing rotation groups of the CPS (in interviews 4

\footnotetext{
${ }^{18}$ This is essentially the calibration strategy used by Bils, Chang and Kim (2012). More precisely, they choose the variance of match-specific productivities to match the average separation rate for each group.

${ }^{19}$ Formally, it can be shown that the change in the separation rate in response to aggregate productivity shocks is

$$
\left.\frac{d \ln F\left(R_{i}\right)}{d \ln z}\right|_{z=1}=\frac{f_{i}\left(R_{i}\right)}{F_{i}\left(R_{i}\right)} \frac{d R_{i}}{d z}
$$

where $\frac{f_{i}\left(R_{i}\right)}{F_{i}\left(R_{i}\right)}$ is the inverse Mills ratio for the empirical distribution of match productivity. Note that for many distributions and, in particular, for the (log) normal distribution, the inverse Mill ratio is $\frac{f_{i}\left(R_{i}\right)}{F_{i}\left(R_{i}\right)}$ is decreasing in the variance of match productivities. Therefore, for a given $\frac{d R_{i}}{d z}$, the cyclicality of the separation rate is decreasing in the variance of match productivities.
} 
Table 5. Wage dispersion by wage and education group

\begin{tabular}{|c|c|c|}
\hline By wage group & $\mathbf{s d}(\mathbf{l w})$ & $\operatorname{sd}(\mathbf{d l l w})$ \\
\hline Below median & 0.36 & 0.45 \\
\hline Above median & 0.40 & 0.42 \\
\hline By education group & sd(lw) & $\operatorname{sd}(\mathrm{dllw})$ \\
\hline HS degree or less & 0.50 & 0.41 \\
\hline Some college or more & 0.60 & 0.49 \\
\hline $\begin{array}{l}\text { Notes: sd stands for standa } \\
\text { the difference in the log ho } \\
\text { interview (which are exact } \\
\text { years 1979-2008. }\end{array}$ & $\begin{array}{l}\text { log hour } \\
\text { 8th and } \\
\text { ce: CPS }\end{array}$ & $\begin{array}{l}\text { and dlw fo } \\
\text { CPS } \\
\text { iles for the }\end{array}$ \\
\hline
\end{tabular}

and 8). If the log wage in the model is decomposed into $w_{i}^{a}+w_{i t}^{x}+w_{t}^{z}$, where $w_{i}^{a}$ is a workerspecific effect, $w_{i t}^{x}$ a match-specific productivity effect and $w_{t}^{z}$ an aggregate productivity effect, then we get that

$$
d \log w_{i t}=d w_{i t}^{x}+d w_{t}^{z} .
$$

Further, assuming that the distributions of match productivity shocks and aggregate shocks are constant over time and independent of each other, we get:

$$
\operatorname{Var}\left(d \log w_{i t}\right)=2 \operatorname{Var}\left(w_{i t}^{x}\right)\left(1-\rho_{x}\right)+2 \operatorname{Var}\left(w_{t}^{z}\right)\left(1-\rho_{z}\right),
$$

where $\rho_{x}$ and $\rho_{z}$ are the autocorrelations of match-specific and aggregate productivity shocks. If the variance of match productivity shocks differs across wage groups, we should observe differences in the variance of wage changes. However, in the CPS data, the variance of wage changes is similar across the two wage groups. Table 5 shows that the standard deviation of the yearly wage growth rate is almost the same across the two wage groups (and higher for those with some college education or more). To sum up, there seems to be little justification for assuming a higher variance of match productivity shocks for the low-ability group.

\subsection{Wage Rigidity}

How about other prospective explanations for the different cyclicality of separations of low and high-wage workers? ${ }^{20}$ One possible explanation is that wage rigidity leads to more cyclical separations for high-wage workers as the failure of adjusting the wage in response to an aggregate shock results in the firm firing the worker. The rigid-wage hypothesis,

\footnotetext{
${ }^{20}$ In a previous version of this paper, I also explored whether differences in bargaining power $\left(\alpha_{i}\right)$ across worker types could explain the documented patterns, but found that workers with high bargaining power (and thus high wages) have less cyclical separations.
} 
however, faces several difficulties in explaining the pattern in the CPS data. First, the wage observations in the CPS sample are 9-12 months prior to the the observed separation. Gottschalk (2005) shows that wages are usually renegotiated one year after the last change, which implies that for most records in my sample wages were renegotiated between interview 4 and the subsequent interviews 9-12 months later. Naturally, it is possible that wages are renegotiated but still display substantial rigidity if the renegotiation only results in a small wage adjustment.

Second, and more importantly, wage rigidity does not necessarily lead to more cyclical separations for high-wage workers. In particular, if the contribution of match-specific productivity shocks $x$ to the variance of total match productivity $z x a_{i}$ is large, it is very difficult to generate a model where wage rigidity leads to more cyclical separations for highwage workers. If wages fail to adjust in response to match-specific productivity shocks, then high-wage workers should also be more likely to be fired in good times. In the data, aggregate shocks to labor productivtiy are rather small and, in particular, small compared to matchspecific shocks. In my baseline calibration above, the standard deviation of match-specific shocks is 7.5 times higher than the standard deviation of aggregate shocks. Match-specific shocks are not observed but inferred from wage data, and reducing the standard deviation of match-specific productivity shocks would be at odds with data on cross-sectional wage dispersion.

Finally, sticky wages affect separations because wages fail to adjust when they fall outside the bargaining set (the range within which the surplus for both parties is positive). This implies that separations may occur even if the joint surplus is positive: when wages are too high, the firm fires the worker, whereas when wages are too low the worker quits. In both cases, however, the parties would be better off by renegotiating the wage and thus these separations are bilaterally inefficient. Another possibility would be to let wages adjust to the boundary of the bargaining set whenever they are about to leave it. In such a model, however, wage rigidity has little impact on separations as this type of wage rigidity affects how the suprlus is split, but only has a limited impact on the total surplus. ${ }^{21}$ As long as separations occur only when the total surplus is negative - i.e., as long as separations are efficient - the model is similar to a model with flexible wages and thus unlikely to explain the empirical patterns of separations I have documented in the CPS data.

\footnotetext{
${ }^{21}$ Naturally, wage rigidity may have an allocative role on hiring, as emphasized in a recent literature by Hall (2005), Hall and Milgrom (2008), van Rens et al. (2009) and others.
} 
Table 6. Model with firm death shocks: The cyclicality of separation and job-finding rates

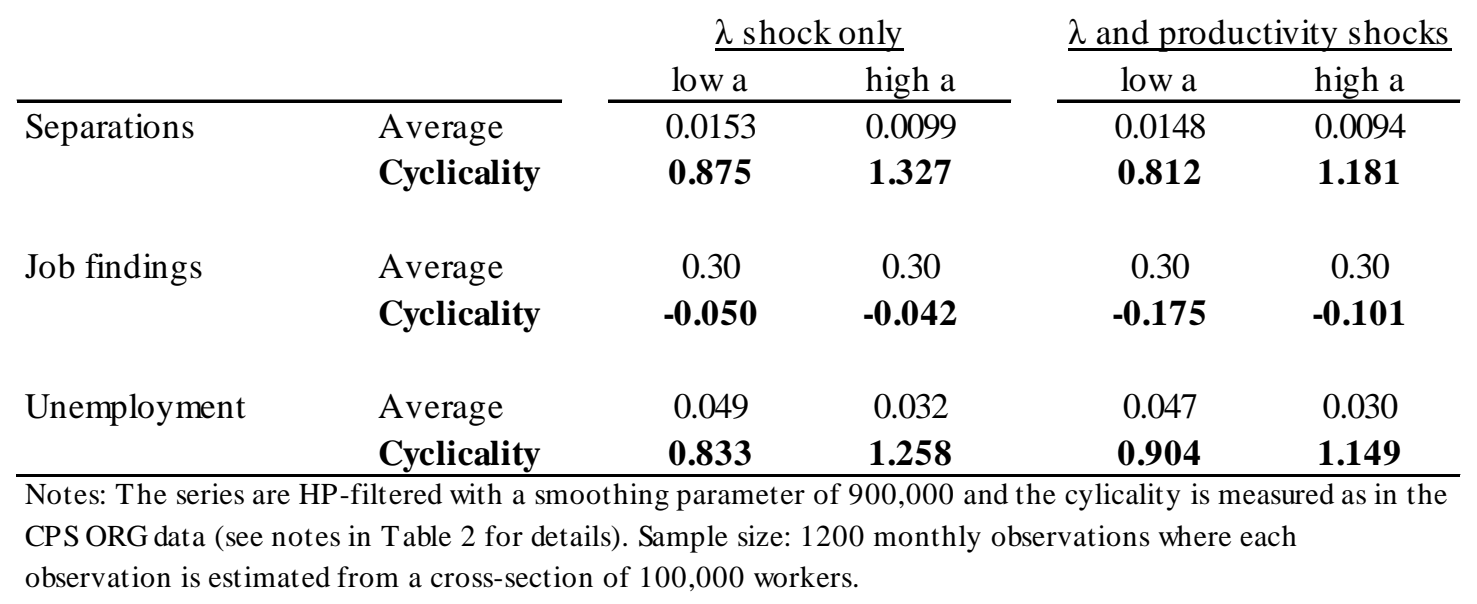

\subsection{Firm and Plant Death}

Another reason why separations are more cylical for workers with high ability could be that separations in recessions are driven by the death of firms and plants. In fact, there is ample evidence that firm and plant death is countercylical (see Davis, Haltiwanger and Schuh, 1996; Figura, 2006). If workers of different ability are randomly distributed across firms, then plant death will increase separations for workers of all types by the same absolute number, and more in percentage terms for those with low average separation rates (high-ability workers). A simple way of modeling such shocks is to introduce an exogenous firm death shock. In the benchmark model with one employee per firm, this is equivalent to an exogenous separation shock. Figura (2006) shows that the yearly plant death rate increased from bottom to peak by approximately 5 percentage points in the 1981/1982 recession and by 7 percentage points in the 1991 recession. The average of these two recessions corresponds to an increase in the monthly death rate of approximately 0.5 percentage points. For this reason, I extend my benchmark model from above by assuming that firms are hit by a death shock $(\lambda)$ with a $0.5 \%$ probability per month in recessions and with zero probability in booms. As expected, Table 6 shows that separations in this model are more cyclical but on average lower for high-ability workers, as in the CPS data. However, the models fails in fully accounting for the differences in the cyclicality of separations between low- and high-ability workers. With firm and plant death shocks, differences in the cyclicality of separations only come from differences in the average separation rates. More precisely, it can be shown that in the presence of such shocks alone, the ratio of the cyclicality of separation rates is $\frac{\beta_{\text {low }}^{\text {sep }}}{\beta_{\text {high }}^{\text {sep }}} \approx \frac{\bar{s}_{\text {high }}}{\bar{s}_{\text {low }}}$, where $\bar{s}_{i}$ denotes the average separation rate of group $i$. The ratio of the average separation rates between lowand high-wage workers in the CPS is 0.61 , whereas the ratio of the cylicality of separation rates in the CPS is 0.54 . In other words, a model with only firm and plant death shocks 
cannot fully explain the differences in cyclicality of separations in the CPS. As explained above, productivity shocks tend to shift separations in the opposite direction and thus, they make it even more difficult to fully match the differences found in the data.

\section{Credit-Constraint Shocks}

Recessions are often periods where access to credit becomes more difficult. ${ }^{22}$ Because of a shortfall of productivity in the short term, firms might therefore be forced to close down projects that would be profitable in the long term. How does such a credit-tightening affect job separations? And, in particular, does it affect matches with workers of low and high ability in a different way?

To more formally evaluate these questions, I incorporate credit-constraint shocks into my benchmark model. I use a short-cut by assuming that in recessions, worker-firm matches face a constraint to produce cash flows above some negative number $\gamma(z)$ :

$$
z x a_{i}-w_{i}(z, x) \geq \gamma(z)
$$

Naturally, workers may be willing to deviate from the Nash bargained wage and take a wage cut in order to continue the relationship. For this reason, wages are assumed to satisfy the Nash-bargaining solution $w_{i}^{N B}(z, x)$ as long as the cash-flow constraint (13) can be met, but otherwise adjust to meet the constraint:

$$
w_{i}(z, x)=\left\{\begin{array}{cc}
w_{i}^{N B}(z, x) & \text { if } z x a_{i}-w_{i}^{N B}(z, x) \geq \gamma(z) \\
z x a_{i}-\gamma(z) & \text { if } z x a_{i}-w_{i}^{N B}(z, x)<\gamma(z)
\end{array}\right.
$$

If the cash-flow constraint cannot be met at any acceptable wage for the worker, workerfirm matches will dissolve. The separation condition now states that the worker and the firm are willing to remain in the relationship if their share of the surplus is non-negative:

$$
\begin{aligned}
W_{i}\left(z, R_{i}^{w}(z)\right)-U_{i}(z) & =0 \\
J_{i}\left(z, R_{i}^{f}(z)\right)-V_{i}(z) & =0
\end{aligned}
$$

where $R_{i}^{w}(z)$ is the worker reservation match productivity and $R_{i}^{f}(z)$ is the firm reservation

\footnotetext{
${ }^{22}$ See, e.g., Lown and Morgan (2004) who provide evidence that banks strongly tighten commercial credit standards in recessions. Moreover, Kiyotaki and Moore (1997) provide a theoretical rationale for cyclical variations in borrowing constraints. In their model, small aggregate shocks lead to tighter borrowing constraints through a price effect on collaterals. These effects on borrowing constraints can be large as a reduction in the price of the collateral can lead to a further decline in demand for these assets and thus to a further reduction in the value of the collateral.
} 
match productivity. By (15) and (16), the reservation match productivities differ between worker and firm and separations may occur even if the joint surplus is positive. ${ }^{23}$ Actually, firms never unilaterally fire a worker since cash-flow constraints only impose an upper limit on the wage but not a lower limit (i.e. $R_{i}^{w}(z) \geq R_{i}^{f}(z)$ ).

If workers are willing to take wage cuts to continue the relationship, one may wonder whether cash-flow constraints will ever result in separations. It should be kept in mind, however, that workers are willing to take wage cuts only as long as their share of the surplus remains positive. At the efficient-separation level of match productivity $R_{i}(z)$, for example, workers are not willing to take any wage cut because their surplus from the match is zero. Therefore, a binding cash-flow constraint will always lead to the separation for the matches whose productivity is at, or below, the efficient-separation level of match productivity $R_{i}(z){ }^{24}$ For worker-firm matches with $x>R_{i}(z)$, there is some room for wage adjustment. However, the actual wage cut that the worker may be willing to take is small, because the surplus for those $x$ close to $R_{i}(z)$ is small.

The value functions in this model extension are the same as in the baseline model, except for the value function of the filled vacancy:

$$
J_{i}(z, x)=z x a_{i}-w_{i}(z, x)+\beta E\left[\begin{array}{c}
\sigma_{i}^{w}\left(z^{\prime}, x^{\prime}\right) \max \left\{J_{i}\left(z^{\prime}, x^{\prime}\right), V_{i}\left(z^{\prime}\right)\right\} \\
\left(1-\sigma_{i}^{w}\left(z^{\prime}, x^{\prime}\right)\right) V_{i}\left(z^{\prime}\right)
\end{array} \mid z, x\right],
$$

where $\sigma_{i}^{w}\left(z^{\prime}, x^{\prime}\right)$ takes a value of 1 if the worker stays with the firm and 0 if the worker quits. $^{25}$

\subsection{Results}

I use the same calibration as in the baseline model of Section 3. The only parameter left to calibrate is $\gamma(z)$. Table 7 shows the simulation results for three different values of $\gamma(z)$. I assume it to be $100 \%, 250 \%$ or $400 \%$ of the average cash flow in the unconstrained economy (these values correspond to $\gamma(z)=-0.02, \gamma(z)=-0.05$ and $\gamma(z)=-0.08$, respectively). The average cash flow in this economy is about $2.0 \%$ of average labor productivity. This is similar to other models; e.g., the cash flow in the model of Shimer (2005) is, on average,

\footnotetext{
${ }^{23}$ The assumption here is that wages are renegotiated in every period. In fact, if the firm could commit to pay higher wages in the future when the constraint is no longer binding, the worker-firm match could always be sustained if the total current surplus is positive. However, it is questionnable whether such commitment devices exist, especially because it requires a state contingent path for future wages.

${ }^{24}$ See Model Appendix C2 for a formal proof of this statement.

${ }^{25} \mathrm{~A}$ directed search equilibrium is defined as $R_{i}^{w}(z), R_{i}^{f}(z), w_{i}(z, x), \theta_{i}(z)$ and the value functions $U_{i}(z), W_{i}(z, x), V_{i}(z)$ and $J_{i}(z, x)$ that satisfy: 1 . the Nash-bargaining solution subject to the cash-flow constraint (13), 2. the separation equations (15) and (16), 3. the zero-profit condition: $V_{i}(z)=0$ and 4 . the value functions (7), (8), (9) and (17).
} 
Table 7. Model with credit-cons traint shocks: The cyclicality of separation and job-finding rates

\begin{tabular}{|c|c|c|c|c|c|c|c|}
\hline & \multicolumn{2}{|c|}{$\gamma=-0.02$} & \multicolumn{2}{|c|}{$\underline{\gamma=-0.05}$} & \multicolumn{2}{|c|}{$y=-0.08$} \\
\hline & & low a & high a & low a & high a & low a & high a \\
\hline \multirow[t]{2}{*}{ Separations } & Average & 0.0148 & 0.0094 & 0.0129 & 0.0084 & 0.0126 & 0.0078 \\
\hline & Cyclicality & 1.067 & 1.458 & 0.653 & 1.593 & 0.686 & 1.207 \\
\hline \multirow[t]{2}{*}{ Job findings } & Average & 0.30 & 0.30 & 0.30 & 0.30 & 0.30 & 0.30 \\
\hline & Cyclicality & -0.033 & -0.010 & -0.204 & -0.119 & -0.402 & -0.215 \\
\hline \multirow[t]{2}{*}{ Unemployment } & Average & 0.047 & 0.030 & 0.041 & 0.027 & 0.040 & 0.025 \\
\hline & Cyclicality & 0.882 & 1.184 & 0.700 & 1.458 & 0.868 & 1.211 \\
\hline
\end{tabular}

Notes: The series are HP-filtered with a smoothing parameter of 900,000 and the cylicality is measured as in the CPS ORG data (see notes in Table 2 for details). Sample size: 1200 monthly observations where each observation is estimated from a cross-section of 100,000 workers.

around $1.5 \%$ of average labor productivity. It may be argued that these constraints are very tight as a firm would need just one to four months of average productivity (depending on the calibration of $\gamma$ ) to repay current losses. Note, however, that in this model, match productivity shocks are highly correlated across time and thus, the chances of recovering current losses are far smaller than that.

All my calibrations yield more cyclical separations for high-ability workers. The calibration with the tightest constraint $(\gamma(z)=-0.02)$, however, seems unrealistic as it leads to aggregate separations that are far too cyclical relative to aggregate job findings. The reason is that the constraint is relatively tight, which makes aggregate separations very volatile. The calibrations where $\gamma(z)=-0.05$ and $\gamma(z)=-0.08$ do better in that respect and, at the same time, produce more cyclical separations for high-ability workers. Quantitatively, the model even overpredicts the cyclicality for high-ability workers when $\gamma(z)=-0.05$, whereas it almost exactly matches the ratio of the cyclicality of separations of low- and high-ability workers in the CPS data when $\gamma(z)=-0.08$. It is important to point out that the relationship between the tightness of the constraint in recessions and the magnitude of the compositional shifts is non-monotonic, as the difference in the cyclicality of unemployment rates between the two types is highest at intermediate levels of the cash flow constraint. Therefore, testing the implications of this model extension with macro/time-series data on firm-level financial constraints may be challenging.

\subsection{Discussion}

The important insight of this last model extension is that in the baseline model outlined in Section 3, each worker-firm match produces negative cash flows at the efficient reservation productivity level. As shown in the Model Appendix C2, the firm's cash flows at the 
reservation productivity level $R_{i}(z)$ can be written as:

$$
C F_{i}\left(z, R_{i}(z)\right)=-\beta E\left[\max \left\{(1-\alpha) S_{i}\left(z^{\prime}, x^{\prime}\right), 0\right\} \mid z, R_{i}(z)\right],
$$

This says that cash flows at the reservation productivity level $R_{i}(z)$ are equal to minus the expected future discounted match surpluses $S_{i}$ (times the bargainig share of the firm). Therefore, as long as the firm receives a positive share of the surplus (i.e. $1-\alpha>0$ ), cash flows are negative at $R_{i}(z)$. This can also be seen in Figure 5 , which plots cash flows by matchspecific productivity. Importantly, cash flows are more negative at the reservation match productivity level for high-ability workers than for low-ability workers for two reasons: First, because high-ability workers face lower replacement rates, the reservation match productivity $R_{i}(z)$ is lower and thus cash flows are more negative at $R_{i}(z)$. Second, match surpluses at a given level of $x$ and $z$ are increasing in ability, which implies that at $R_{i}(z)$, cash flows are more negative for high ability workers even if $R_{i}(z)$ is the same for both types. For both of these reasons, separations of high-ability workers are more sensitive to a tightening of credit.

Figure 5: Cash flows by match-specific productivity and worker type

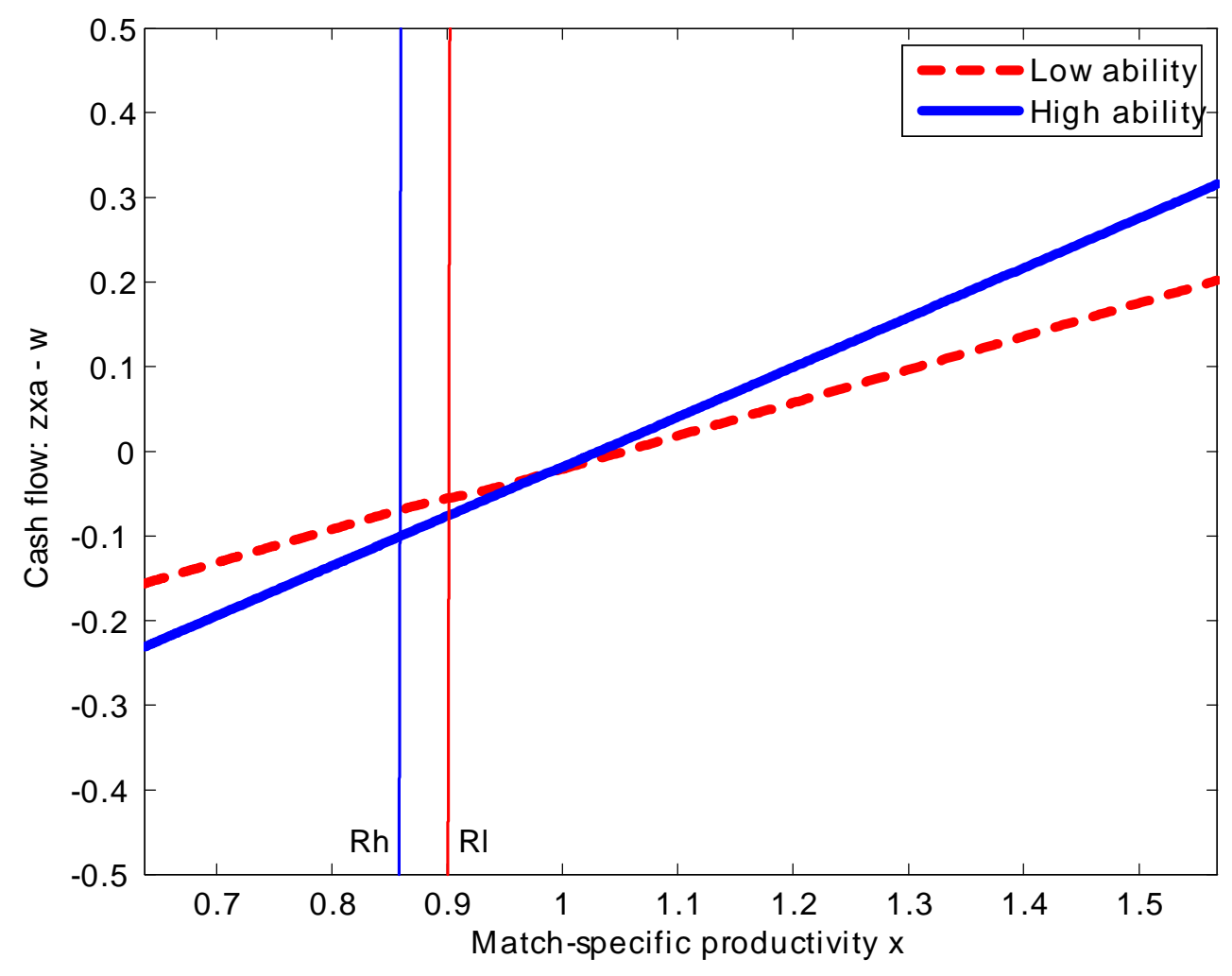

One potential concern may be that, in the model, firms are small in the sense that they only have one employee. It may be argued that if firms had more than one worker, the 
above mechanism would produce different results because the cash-flow constraint would be operating at the firm and not at the match level. In particular, high-ability workers generate a higher surplus for the firm (because of high expected future productivity) and thus, the firm might prefer to lay off low-ability workers in order to keep its high-ability workers. Notice, however, that in a multi-worker firm, each worker-firm relationship has a shadow value of relaxing the cash-flow constraint. This shadow value is increasing more than proportionally with the ability of the worker, because high-ability workers have lower replacement rates and thus, in the unconstrained model, the reservation match productivity is set to a lower level where cash flows are more negative relative to productivity. To put it more simply, if a high-ability worker is twice as productive on average than the low-ability type (i.e., $a_{h}=2 a_{l}$ ), then current cash flows are more than twice as a negative at the reservation match productivity level, and thus the multi-worker firm prefers to fire the highability worker when the cash-flow constraint becomes binding. In addition, if there are small fixed firing costs per worker, then the firm would prefer getting rid off the high-ability worker, even if cash flows were fully proportional to ability. For these reasons, one should expect that - for reasonable assumptions regarding the substitutability between the two types of workers - the main mechanisms in my model to be operative in a multi-worker firm setup.

Ideally, one should set up a multi-worker firm model to investigate the quantitative effects of cash-flow constraints on the cyclicality of separations for low- and high-ability workers. However, such a model is very complicated as the wage bargained by one worker affects the firm-level cash-flow constraint and thus, the wage bargained by other workers. Stole and Zwiebel's (1996) intrafirm bargaining game would be a good starting point, but is further complicated by the presence of low- and high-ability types. This important work is left for future research.

\section{Conclusion}

This paper provides new facts about the composition of the unemployment pool over the U.S. business cycle. In recessions, the pool of unemployed shifts towards workers with high wages in their previous job. Moreover, this change is driven by the higher cyclicality of separations for high-wage workers. These empirical patterns are difficult to explain with a standard search-matching model with endogenous separations and worker heterogeneity, since it predicts shifts in the pool of unemployed in the opposite direction of the data.

I offer two extensions of the model that work better at replicating these new facts. The first extension introduces firm death shocks, which affect all workers indiscriminately of type. However, these shocks cannot fully account for the more cyclical separations of high- 
ability workers because, with such death shocks, differences in the cyclicality of separation rates between low-wage and high-wage individuals are limited by differences in the average separation rates between the two groups. The second extension with credit-constraint shocks, on the other hand, can fully match the differences in the cyclicality of separations between low- and high-ability workers. It is somewhat difficult to exactly pin down the magnitude of these credit-constraint shocks, but my simulations show that the separations of high-ability workers are more cyclical for a broad range of parameter values.

Shifts towards high-ability workers among the unemployed in slumps have important implications for models of aggregate fluctuations of the labor market: if ability is not perfectly observed to potential employers, these shifts pose an additional challenge to the recent literature on the "unemployment volatility puzzle" (see Shimer, 2005). More precisely, these compositional changes aggravate the apparent lack of an amplification mechanism in the standard search-matching model, as they dampen the response of the firms' recruiting behavior to aggregate productivity shocks. Moreover, the shifts may have a large impact on the welfare costs of business cycles as high-ability workers are better able to self-insure against unemployment shocks (see, e.g., Mukoyama and Sahin, 2006). To conduct a proper welfare analysis, however, I have to model the savings and consumption choices of the employed and unemployed. I leave this important task to future research.

Another avenue for future research is to extend my empirical analysis with other data sources. Matched employer-employee data is particularly promising as it allows us to determine the importance of firm death for separations. Moreover, it makes it possible to extract individual fixed effects from the wage and perform the same type of analysis with the average individual effect instead of the average previous wage. It will also be interesting to extend my empirical analysis to other countries. Many European countries have an extensive employment protection legislation, which may affect the sign as well as the magnitude of the shifts in the unemployment pool. E.g., seniority rules make it harder for firms to lay off more experienced workers. But it is unclear how these rules interact with the business cycle, as they may be circumvented or inapplicable in recessions (e.g., because of firm and plant death). ${ }^{26}$ Finally, matched employer-employee data could also be used to test for the importance of credit frictions for the compositional changes in the pool of unemployed, if balance sheet information on the firm side is obtained.

\footnotetext{
${ }^{26}$ Forslund et al. (2011) provide some evidence for Sweden that suggests similar patterns as in the U.S.
} 


\section{References}

[1] Abowd, J., Zellner, A. (1985). "Estimating Gross Labor-Force Flows," Journal of Business 83 Economic Statistics 3(3), 254-83.

[2] Bils, M. (1985). "Real Wages over the Business Cycle: Evidence from Panel Data," Journal of Political Economy 93(4), 666-89.

[3] Bils, M., Chang, Y., Kim, S.-B. (2009). "Comparative Advantage and Unemployment," RCER Working Papers 547, University of Rochester.

[4] Bils, M., Chang, Y., Kim, S.-B. (2012). "Comparative Advantage and Unemployment," Journal of Monetary Economics 59(2), pp. 150-165.

[5] Bleakley, H., Ferris, A., Fuhrer, J. (1999). "New Data on Worker Flows During Business Cycles," New England Economic Review, issue Jul, 49-76.

[6] Davis, S., Haltiwanger, J. and Schuh, S. (1996). Job Creation and Destruction, Cambridge: MIT Press.

[7] Elsby, M., Michaels, R., Solon, G. (2009). "The Ins and Outs of Cyclical Unemployment," American Economic Journal: Macroeconomics 1(1), 84-110.

[8] Fallick, B., Fleischman, Ch. (2004). "Employer-to-Employer Flows in the U.S. Labor Market: The Complete Picture of Gross Worker Flows," Finance and Economics Discussion Series 2004-34, Board of Governors of the Federal Reserve System.

[9] Figura, A. (2006). "Why are Plant Deaths Countercyclical: Reallocation Timing or Fragility?," Finance and Economics Discussion Series 2006-31, Board of Governors of the Federal Reserve System.

[10] Forslund, A., Fredriksson, P., Vikström, J. (2011). "What active labor market policy works best in a recession?" IFAU working paper 2011:2.

[11] Fujita, S., Ramey, G. (2009). "The Cyclicality Of Separation And Job Finding Rates," International Economic Review 50(2), pp. 415-430.

[12] Gottschalk, P. (2005). "Downward Nominal-Wage Flexibility: Real or Measurement Error?," The Review of Economics and Statistics 87(3), 556-68.

[13] Haefke, Ch., Sonntag, M., van Rens, Th. (2012). "Wage Rigidity and Job Creation," CEPR Discussion Paper 8968. 
[14] Hagedorn, M., Manovskii, I. (2008). "The Cyclical Behavior of Equilibrium Unemployment and Vacancies Revisited," American Economic Review 98(4), 1692-1706.

[15] Hall, R. (2005), "Employment Fluctuations with Equilibrium Wage Stickiness", American Economic Review 95(1), 50- 65.

[16] Hall, R., Milgrom, P. (2008). "The Limited Influence of Unemployment on the Wage Bargain," American Economic Review, 98(4), 1653-74.

[17] Hines, J., Hoynes, H., Krueger, A. (2001). "Another Look at Whether a Rising Tide Lifts All Boats" In: Alan B. Krueger and Robert Solow (editors), The Roaring Nineties: Can Full Employment Be Sustained? New York: Russell Sage Foundation.

[18] Kiyotaki, N., Moore, J. (1997). "Credit Cycles," Journal of Political Economy 105(2), 211-48.

[19] Krueger, A., Meyer, B. (2002). "Labor Supply Effects of Social Insurance." In: Alan Auerbach and Martin Feldstein (editors), Handbook of Public Economics Vol 4. NorthHolland: Amsterdam.

[20] Krusell, P., Smith, A. (1998). "Income and Wealth Heterogeneity in the Macroeconomy," Journal of Political Economy 106(5), 867-896.

[21] Lown, C., Morgan, D. (2006). "The Credit Cycle and the Business Cycle: New Findings Using the Loan Officer Opinion Survey," Journal of Money, Credit and Banking 38(6), 1575-1597.

[22] Madrian, B., Lefgren, L. (1999). "A Note on Longitudinally Matching Current Population Survey (CPS) Respondents," NBER Technical Working Papers 0247.

[23] Mukoyama, T., Sahin, A. (2006). "Costs of Business Cycles for Unskilled Workers," Journal of Monetary Economics 53(8), 2179-2193.

[24] Pissarides, C. (2000). Equilibrium Unemployment Theory, MIT Press, Cambridge, MA.

[25] Pries, M. (2008). "Worker Heterogeneity and Labor Market Volatility in Matching Models," Review of Economic Dynamics 11(3), 664-678.

[26] Shimer, R. (2005). "The Cyclical Behavior of Equilibrium Unemployment and Vacancies," American Economic Review 95(1), 25-49.

[27] Shimer, R. (2007). "Reassessing the Ins and Outs of Unemployment," NBER Working Papers 13421. 
[28] Solon, G., Barsky, R., Parker, J. (1994). "Measuring the Cyclicality of Real Wages: How Important Is Composition Bias?," Quarterly Journal of Economics 109(1), 1-25.

[29] Stole, L., Zwiebel, J. (1996). "Organizational Design and Technology Choice under Intrafirm Bargaining," American Economic Review 86(1), 195-222.

[30] Tauchen, G. (1986). "Finite State Markov-Chain Approximations to Univariate and Vector Autoregressions", Economics Letters 20, 177-181. 


\section{Appendix}

\section{A1. CPS Outgoing Rotation Group and monthly files (1979-2008)}

\section{A1.1 Hourly wage series}

I use the CPS ORG files provided by the Center for Economic and Policy Research (CEPR). These files are based on the NBER version of the CPS ORG files, and include additional wage series that adjust the NBER series of the hourly wage for overtime earnings, tips and commissions, and impute earnings above the top code. Earnings above the top code are imputed based on assuming a distribution of wages, and I choose the variable w_ln_ot, which assumes a logarithmic distribution of earnings. As Haefke et al. (2012), I deflate nominal hourly wages with the implicit deflator for hourly earnings in the private non-farm business sector from the BLS productivity and costs program. To address potential issues related to outliers, I drop all wage observations below the 0.25th and above the 99.75th percentile in each year, as well as drop individuals who work less than 5 hours or more than 80 hours.

\section{A1.2 Matching}

Due to moves into and out of household addresses, invalid matches must be eliminated based on demographic information. I use the s|r|a criterion of Madrian and Lefgren (1999), because it appears to yield a relatively good trade-off between accepting invalid matches and rejecting valid matches. The criterion keeps as valid matches only those observations with the same sex, race and an age difference of $0-2$ years.

To match the different interviews, I proceed in two steps: First, I match the eighth interview from the CPS ORG data to the fourth interview in the CPS ORG data and then, second, I match the additional monthly interviews 5, 6 and 7 to the fourth interview.

\section{A1.3 Industry and occupation codes}

At the 2-digit level, the NBER created industry that are consistent across all years. At the 3-digit level, the occupation and industry classification in the CPS ORG files changed coding scheemes in 1983, 1992 and 2003. I use the variables occ1950 and ind1950 from the IPUMS-CPS, which is a harmonized 3-digit occupation and industry scheeme across all years. 


\section{A1.4 Mincerian wage regressions}

In part of the analysis in Section 2, I use wage residuals. The regression I run to create these residuals, is the log hourly wage on potential expericence (quadratic polynomial), educational attainment, gender, marital status, an interaction term between marital status and gender, dummies for black, hispanic and other race and dummies for each state, year, occupation and industry. Potential experience is defined as age minus years of school and minus 6 . In order to take into account for changes in the coefficients of the regression over time, I run the regression for each year in a rolling window (i.e., including data from plus and minus five years) and then compute the residual for that year.

\section{A2. CPS March files (1962-2011)}

I use the CPS-IPUMS version of the CPS March supplement. As mentioned in the main text, the CPS March supplement does not contain a measure of hours worked on the previous job for the period prior to 1976. For this reason, I use the weekly wage. The weekly wage is derived from the variable of total wage and salary income during the previous calendar year and then divided by the number of weeks worked during the previous calendar year. For the period prior to 1976 the measure of weeks worked is only available as a categorical variable, and I impute the weeks worked by the midpoint of each interval from data for the period 1976 and onwards (the intervals are 1-13 weeks, 14-26 weeks, 27-39 weeks, 40-47 weeks, 48-49 weeks and 50-52 weeks). As in the CPS ORG and monthly data, I deflate nominal hourly wages with the implicit deflator for hourly earnings in the private non-farm business sector from the BLS productivity and costs program, and drop all wage observations below the 0.25 th and above the 99.75th percentile in each year. I use the same industry and occupation classification scheme and run the same wage regressions as in the analysis with the CPS ORG and monthly data.

\section{B. The relationship between changes in the composition of the un- employed and changes in the composition of the employed}

Let's divide the pool of employed in two equally large group, i.e., into those below and above the median. The share of unemployed and the share of employed of group $i$ then can be written as:

$$
\begin{aligned}
\phi_{i t}^{U} & =\psi_{i} \frac{U_{i t}}{U_{t}} \\
\phi_{i t}^{E} & =\psi_{i} \frac{E_{i t}}{E_{t}}
\end{aligned}
$$


where $i$ stands for low or high, and where $\psi_{i}$ is the population share of group $i$. The changes in the shares then can be written as

$$
\begin{aligned}
d \phi_{i t}^{U} & =\phi_{i t}^{U}\left[d \ln U_{i t}-d \ln U_{t}\right] \\
d \phi_{i t}^{E} & =\phi_{i t}^{E}\left[d \ln E_{i t}-d \ln E_{t}\right] \\
& =\phi_{i t}^{E}\left[d \ln \left(1-U_{i t}\right)-d \ln \left(1-U_{t}\right)\right]
\end{aligned}
$$

and where the latter can be approximated as

$$
\begin{aligned}
d \phi_{i t}^{E} & \approx \phi_{i t}^{E}\left[d U_{t}-d U_{i t}\right] \\
& \approx \phi_{i t}^{E}\left[U_{t} d \ln U_{t}-U_{i t} d \ln U_{i t}\right] \\
& \approx \phi_{i t}^{E}\left[U_{t} d \ln U_{t}-\frac{U_{i t}}{\phi_{i t}^{U}}\left(d \phi_{i t}^{U}+\phi_{i t}^{U} d \ln U_{t}\right)\right] \\
& \approx \phi_{i t}^{E} U_{t}\left[-\frac{1}{\psi_{i}}\left(d \phi_{i t}^{U}\right)+\frac{\left(U_{t}-U_{i t}\right)}{U_{t}} d \ln U_{t}\right] \\
& \approx \phi_{i t}^{E}\left[-2 U_{t}\left(d \phi_{i t}^{U}\right)+\left(1-2 \phi_{i t}^{U}\right) d U_{t}\right]
\end{aligned}
$$

and using the averages and the cyclicality of unemployment by wage group from Table 2 , we get:

$$
\begin{aligned}
\frac{d \phi_{\text {high }, t}^{U}}{d U_{t}} & =\frac{\phi_{\text {high }, t}^{U}}{U_{t}}\left[\frac{d \ln U_{\text {high }, t}}{d \ln U_{t}}-1\right] \\
& =\frac{0.39}{0.0305}(1.25-1) \\
& =3.2 \\
\frac{d \phi_{\text {high }, t}^{E}}{d U_{t}} & \approx \phi_{\text {high }, t}^{E}\left[-2 U_{t}\left(\frac{d \phi_{\text {high }, t}^{U}}{d U_{t}}\right)+\left(1-2 \phi_{\text {high }, t}^{U}\right)\right] \\
& \approx 0.5[-2(0.0305)(3.2)+(1-2(0.39))] \\
& \approx 0.012
\end{aligned}
$$

where $U_{t}=\frac{U_{\text {low }, t}+U_{\text {high }, t}}{2}=0.0305$, where $\phi_{\text {high }, t}^{U}=\psi_{\text {high }} \frac{U_{\text {high }, t}}{U_{t}}=0.5 \frac{0.024}{0.0305}=0.39$ and where I have assumed that $\phi_{\text {high }, t}^{E}=\psi_{i} \frac{E_{i t}}{E_{t}}=0.5 \frac{E_{i t}}{E_{t}} \approx 0.5$ at all times.

\section{C1. A Search-Matching Model with Non-Directed Search}

If search on the firm side is non-directed to a particular worker type, then there is only one aggregate matching function:

$$
M=\kappa u^{\eta} v^{1-\eta} .
$$


Note that in this model, there is an important interaction between the labor markets of low- and high-ability types, as the composition of the pool of unemployed is of importance for the firm's chances of meeting the high-ability types and thus affects the incentives for posting vacancies.

The value functions of the worker are the same as before:

$$
\begin{aligned}
U_{i}(Z) & =b_{i}+\beta E\left[\left(1-f\left(\theta_{i}\right)\right) U_{i}\left(Z^{\prime}\right)+f\left(\theta_{i}\right) W_{i}\left(Z^{\prime}, \bar{x}\right) \mid Z\right] \\
W_{i}(Z, x) & =w_{i}(Z, x)+\beta E\left[\max \left\{W_{i}\left(Z^{\prime}, x^{\prime}\right), U_{i}\left(Z^{\prime}\right)\right\} \mid Z, x\right],
\end{aligned}
$$

whereas the value functions of the firm are now:

$$
\begin{aligned}
V(Z)= & -c+\beta E\left[(1-q(\theta)) V\left(Z^{\prime}\right)\right. \\
& \left.+q(\theta)\left(\pi J_{l}\left(Z^{\prime}, \bar{x}\right)+(1-\pi) J_{h}\left(Z^{\prime}, \bar{x}\right)\right) \mid Z\right] \\
J_{i}(Z, x)= & z x a_{i}-w_{i}(Z, x)+\beta E\left[\max \left\{J_{i}\left(Z^{\prime}, x^{\prime}\right), V\left(Z^{\prime}\right)\right\} \mid Z, x\right],
\end{aligned}
$$

where the imporant difference is that the value of the vacancy is now independent of type, as firms post vacancies for all types of workers. This implies that the value of posting a vacancy depends on the share of the low-ability types in the pool of unemployed $(\pi)$.

A non-directed search equilibrium is defined as $R_{i}(Z), w_{i}(Z, x), \theta(Z)$ and the value functions $U_{i}(Z), W_{i}(Z, x), V(Z)$ and $J_{i}(Z, x)$ that satisfy: 1 . the Nash-bargaining solution (11), 2. the efficient-separation equation (12), 3. the zero-profit condition: $V(Z)=0$ and 4 . the value functions (22), (23), (24) and (25).

Note that in the non-directed search equilibrium, the group-specific unemployment rates and the distribution of types across match productivities are aggregate state variables. The reason is that the firms' decision to post a vacancy depends on the share of low types in the pool of unemployed in the current as well as in future periods. The distribution of worker types across match productivties $x$ is needed to forecast the share of low types in the future, because the more workers of one type are close to the productivity threshold where separations occur, the more likely this share is to increase for that group in the future. This complicates the analysis considerably as it is generally not possible to solve a model with a highly dimensional state space such as with the distribution of worker types across match productivties. For this reason, I only do the comparative statitics for the non-directed search model because in the steady state, the distribution of worker types is constant across time. I leave it to future work to compute an approximate equilibrium with a limited set of aggregate state variables similar to Krusell and Smith's (1998) method in models with heterogeneity in asset holdings. Appendix Tables A.5, A.6 and A.7 show the comparative 
statics results for the directed and non-directed search model. The results between the two models are similar; in particular, the differences in the cyclicality of separations between the low- and high-ability types are not affected to any considerable extent by the modeling choices on non-directed or directed search.

\section{C2. A Search-Matching Model with Cash-Flow Constraints}

This appendix provides formal propositions and proofs of the intuition explained in the text.

Proposition 1 At the efficient reservation match productivity $R_{i}(z)$, the firm's cash flows are negative if the firm's bargaining share is larger than 0.

Proof. At $R_{i}(z)$, the joint surplus of the match is zero, as well as the surplus share of the firm. Because of the zero-profit condition, we get:

$$
\begin{aligned}
0 & =J_{i}(z, R(z))-V_{i}(z) \\
& =J_{i}(z, R(z)) \\
& =C F_{i}(z, R(z))+\beta E\left[\max \left\{J_{i}\left(z^{\prime}, x^{\prime}\right), 0\right\} \mid z, R_{i}(z)\right],
\end{aligned}
$$

and thus

$$
\begin{aligned}
C F_{i}\left(z, R_{i}(z)\right) & =-\beta E\left[\max \left\{J_{i}\left(z^{\prime}, x^{\prime}\right), 0\right\} \mid z, R_{i}(z)\right] \\
& =-\beta E\left[\max \left\{(1-\alpha) S_{i}\left(z^{\prime}, x^{\prime}\right), 0\right\} \mid z, R_{i}(z)\right],
\end{aligned}
$$

which says that cash flows have to be negative at the efficient reservation match productivity level if the firm expects a surplus from the match in the future, i.e., if the firm's surplus share is positive $(1-\alpha>0)$. This holds for any process of match productivity with some positive probability of a higher match productivity in future periods.

Proposition 2 At the efficient reservation match productivity $R_{i}(z)$, wages do not adjust in response to a credit-constraint shock, and matches separate if the constraint is binding.

Proof. At the efficient reservation match productivity, the total match surplus as well as the worker share of the surplus is zero. Therefore, the worker is not willing to take a wage cut, because it would result in a negative surplus share for the worker.

Proposition 3 If $b_{i}=b a_{i}$ and $f\left(\theta_{i}\right)=f$, then, at the efficient reservation match productivity $R_{i}(z)$, cash flows are more negative for high-ability workers. 
Proof. From the proposition above, we know that the cash flow at the reservation match productivity level depends on the discounted future expected surplus. So if the expected surplus is higher for high-ability workers, then cash flows are more negative at $R_{i}(z)$. If $b_{i}=b a_{i}$, then the surplus can be written as:

$$
\begin{aligned}
S_{i}(z, x)= & W_{i}(z, x)-U_{i}(z)+J_{i}(z, x) \\
= & a_{i}(z x-b)+\beta E\left[\max \left\{S_{i}\left(z^{\prime}, x^{\prime}\right), 0\right\} \mid z, x\right] \\
& -\beta f\left(\theta_{i}\right) \alpha E\left[\max \left\{S_{i}\left(z^{\prime}, \bar{x}\right), 0\right\} \mid z\right],
\end{aligned}
$$

and if $f\left(\theta_{i}\right)=f(\theta)$, then

$$
S_{i}(z, x)=a_{i} \tilde{S}(z, x),
$$

where $\tilde{S}(z, x) \geq 0$ is independent of ability. This implies that the surplus is increasing proportionally to ability and thus cash flows at $R_{i}(z)$ are more negative for high-ability workers.

It follows that if $\frac{d b_{i}}{d a_{i}}=0$, cash flows at the reservation match productivity level are even more negative for high-ability workers, since the surplus is even higher for high-ability workers. Note that the assumption that the job-finding rates are the same for the two groups is not necessarily met: the model calibration targets the average job-finding rate to be 0.3 for both groups, but the job-finding rates are allowed to differ over the cycle. 


\section{Appendix Tables}

Table A.1 The cyclicality of separation rates, by wage group (robustness checks)

\begin{tabular}{|c|c|c|c|c|c|}
\hline & & $\underline{\log (\mathrm{hol}}$ & wage) & Mince & sidual \\
\hline & & low & high & low & high \\
\hline Full sample (Baseline) & $\begin{array}{l}\text { Cyclicality } \\
\text { (s.e.) }\end{array}$ & $\begin{array}{l}\mathbf{0 . 4 0} \\
(0.078)^{*+* *}\end{array}$ & $\begin{array}{c}\mathbf{0 . 7 4} \\
(0.096)^{*+* k}\end{array}$ & $\begin{array}{l}\mathbf{0 . 4 3} \\
(0.063)^{*+k t}\end{array}$ & $\begin{array}{l}\mathbf{0 . 6 8} \\
(0.077)^{* * *}\end{array}$ \\
\hline $\begin{array}{l}\text { Extended sample: Unemployed AND } \\
\text { out of the labor force }\end{array}$ & $\begin{array}{l}\text { Cyclicality } \\
\text { (s.e.) }\end{array}$ & $\begin{array}{l}\mathbf{0 . 0 5} \\
(0.043)\end{array}$ & $\begin{array}{l}\mathbf{0 . 3 0} \\
(0.054)^{* \star *}\end{array}$ & $\begin{array}{l}\mathbf{0 . 0 7} \\
(0.046)\end{array}$ & $\begin{array}{c}\mathbf{0 . 2 4} \\
(0.054)^{* * *}\end{array}$ \\
\hline $\begin{array}{l}\text { Subsample: not on temporary layoff } \\
\text { (1988-2008 only) }\end{array}$ & $\begin{array}{l}\text { Cyclicality } \\
\text { (s.e.) }\end{array}$ & $\begin{array}{c}\mathbf{0 . 4 0} \\
(0.087)^{+* * *}\end{array}$ & $\begin{array}{c}\mathbf{0 . 7 3} \\
(0.141)^{\star \star *}\end{array}$ & $\begin{array}{l}\mathbf{0 . 3 8} \\
(0.107)^{* \star *}\end{array}$ & $\begin{array}{l}\mathbf{0 . 7 5} \\
(0.097)^{* * *}\end{array}$ \\
\hline Subsample: age $25-54$ & $\begin{array}{l}\text { Cyclicality } \\
\text { (s.e.) }\end{array}$ & $\begin{array}{l}\mathbf{0 . 4 2} \\
(0.083)^{* * * *}\end{array}$ & $\begin{array}{l}\mathbf{0 . 7 5} \\
(0.077)^{*+*}\end{array}$ & $\begin{array}{l}\mathbf{0 . 4 4} \\
(0.071)^{\star * \star}\end{array}$ & $\begin{array}{c}\mathbf{0 . 7 3} \\
(0.073)^{* * *}\end{array}$ \\
\hline Subsample: men & $\begin{array}{l}\text { Cyclicality } \\
\text { (s.e.) }\end{array}$ & $\begin{array}{l}\mathbf{0 . 4 5} \\
(0.076)^{*+* *}\end{array}$ & $\begin{array}{l}\mathbf{0 . 7 3} \\
(0.081)^{* * *}\end{array}$ & $\begin{array}{l}\mathbf{0 . 4 9} \\
(0.064)^{*+* *}\end{array}$ & $\begin{array}{c}\mathbf{0 . 7 2} \\
(0.083)^{*+*}\end{array}$ \\
\hline Subs ample: full-time workers & $\begin{array}{l}\text { Cyclicality } \\
\text { (s.e.) }\end{array}$ & $\begin{array}{l}\mathbf{0 . 3 7} \\
(0.083)^{* * * *}\end{array}$ & $\begin{array}{c}\mathbf{0 . 7 3} \\
(0.098)^{* \star *}\end{array}$ & $\begin{array}{l}\mathbf{0 . 4 1} \\
(0.067)^{*+*}\end{array}$ & $\begin{array}{c}\mathbf{0 . 6 8} \\
(0.080)^{* * *}\end{array}$ \\
\hline Subsample: some college or more & $\begin{array}{l}\text { Cyclicality } \\
\text { (s.e.) }\end{array}$ & $\begin{array}{l}\mathbf{0 . 4 2} \\
(0.119)^{* \star \star}\end{array}$ & $\begin{array}{l}\mathbf{0 . 7 2} \\
(0.108)^{\star \star \star \star}\end{array}$ & $\begin{array}{l}\mathbf{0 . 4 5} \\
(0.103)^{\star \star *}\end{array}$ & $\begin{array}{c}\mathbf{0 . 7 5} \\
(0.091)^{\star \star \star \star}\end{array}$ \\
\hline $\begin{array}{l}\text { Subsample: not manufacturing and } \\
\text { not construction }\end{array}$ & $\begin{array}{l}\text { Cyclicality } \\
\text { (s.e.) }\end{array}$ & $\begin{array}{c}\mathbf{0 . 4 3} \\
(0.067)^{* * * *}\end{array}$ & $\begin{array}{l}\mathbf{0 . 7 3} \\
(0.137)^{\star \star \star *}\end{array}$ & $\begin{array}{c}\mathbf{0 . 4 3} \\
(0.059)^{* * *}\end{array}$ & $\begin{array}{c}\mathbf{0 . 7 0} \\
(0.099)^{* \star * *}\end{array}$ \\
\hline $\begin{array}{l}\text { Filtering: HP-filtered with smoothing } \\
\text { parameter } 14400\end{array}$ & $\begin{array}{l}\text { Cyclicality } \\
\text { (s.e.) }\end{array}$ & $\begin{array}{c}\mathbf{0 . 5 4} \\
(0.163)^{* * *}\end{array}$ & $\begin{array}{l}\mathbf{1 . 0 6} \\
(0.167)^{\star \star \star \star}\end{array}$ & $\begin{array}{c}\mathbf{0 . 6 2} \\
(0.109)^{* * *}\end{array}$ & $\begin{array}{c}\mathbf{0 . 9 8} \\
(0.161)^{* * *}\end{array}$ \\
\hline $\begin{array}{l}\text { Filtering: Not filtered, but controlling } \\
\text { for linear trend }\end{array}$ & $\begin{array}{l}\text { Cyclicality } \\
\text { (s.e.) }\end{array}$ & $\begin{array}{c}\mathbf{0 . 3 9} \\
(0.055)^{*+* *}\end{array}$ & $\begin{array}{c}\mathbf{0 . 7 6} \\
(0.064)^{*+* k}\end{array}$ & $\begin{array}{c}\mathbf{0 . 4 2} \\
(0.051)^{* * *}\end{array}$ & $\begin{array}{c}\mathbf{0 . 6 9} \\
(0.061)^{* \star * *}\end{array}$ \\
\hline Adjusted for time aggregation bias & $\begin{array}{l}\text { Cyclicality } \\
\text { (s.e.) }\end{array}$ & $\begin{array}{c}\mathbf{0 . 2 9} \\
(0.080)^{* * *}\end{array}$ & $\begin{array}{c}\mathbf{0 . 6 0} \\
(0.104)^{* \star \star *}\end{array}$ & $\begin{array}{c}\mathbf{0 . 3 0} \\
(0.067)^{* * *}\end{array}$ & $\begin{array}{c}\mathbf{0 . 5 5} \\
(0.082)^{*+*}\end{array}$ \\
\hline $\begin{array}{l}\text { Notes: Newey-West corrected standard err } \\
\text { significant at } 1 \% \text {. All series are HP-filterec } \\
\text { cylicality is measured as the coefficient } \beta \text { i } \\
\text { job-finding or unemployment rate of group } \\
\text { Chang and Kim (2009), I instrument the s} \\
\text { of measurement error. Sample size: } 322 \mathrm{~m} \\
\text { CPS Out going Rotation Group and CPS mo }\end{array}$ & $\begin{array}{l}\text { ors in parenthe } \\
\text { with a smooth } \\
\text { in the regressior } \\
\text { i at time } t \text { and } \\
\text { ample unemplo } \\
\text { onthly observa }\end{array}$ & $\begin{array}{l}\text { is the san } \\
\text { ent rate wi }\end{array}$ & unemplo & ployme & $\begin{array}{l}* * * \\
\text { ited). The } \\
\text { aration, } \\
\text { to Bils, } \\
\text { e because } \\
\text { from the }\end{array}$ \\
\hline
\end{tabular}


Table A.2 The cyclicality of job-finding rates, by wage group(robustness checks)

\begin{tabular}{|c|c|c|c|c|c|}
\hline & & $\underline{\log (h o u}$ & wage) & $\underline{\text { Mince }}$ & sidual \\
\hline & & low & high & low & high \\
\hline Full sample (Baseline) & $\begin{array}{l}\text { Cyclicality } \\
\text { (s.e.) }\end{array}$ & $\begin{array}{l}\mathbf{- 0 . 5 6} \\
(0.054)^{* * *}\end{array}$ & $\begin{array}{l}-\mathbf{- 0 . 7 0} \\
(0.072)^{* * *}\end{array}$ & $\begin{array}{l}\mathbf{- 0 . 6 5} \\
(0.059)^{* * *}\end{array}$ & $\begin{array}{l}-\mathbf{- 0 . 6 0} \\
(0.064)^{* k *}\end{array}$ \\
\hline $\begin{array}{l}\text { Extended sample: Unemployed AND } \\
\text { out of the labor force }\end{array}$ & $\begin{array}{l}\text { Cyclicality } \\
\text { (s.e.) }\end{array}$ & $\begin{array}{l}\mathbf{- 0 . 3 7} \\
(0.073)^{* * *}\end{array}$ & $\begin{array}{l}\mathbf{- 0 . 4 7} \\
(0.062)^{\star \star *}\end{array}$ & $\begin{array}{l}\mathbf{- 0 . 4 1} \\
(0.063)^{* * *}\end{array}$ & $\begin{array}{l}\mathbf{- 0 . 4 3} \\
(0.058)^{* * *}\end{array}$ \\
\hline $\begin{array}{l}\text { Subsample: not on temporary layoff } \\
\text { (1988-2008 only) }\end{array}$ & $\begin{array}{l}\text { Cyclicality } \\
\text { (s.e.) }\end{array}$ & $\begin{array}{l}-\mathbf{- 0 . 6 2} \\
(0.068)^{* \star *}\end{array}$ & $\begin{array}{l}\mathbf{- 0 . 8 5} \\
(0.117)^{\star \star \star}\end{array}$ & $\begin{array}{l}\mathbf{- 0 . 7 3} \\
(0.089)^{* * *}\end{array}$ & $\begin{array}{l}\mathbf{- 0 . 7 3} \\
(0.078)^{* \star * *}\end{array}$ \\
\hline Subsample: age $25-54$ & $\begin{array}{l}\text { Cyclicality } \\
\text { (s.e.) }\end{array}$ & $\begin{array}{l}-\mathbf{- 0 . 5 2} \\
(0.069)^{* * *}\end{array}$ & $\begin{array}{l}\mathbf{- 0 . 6 8} \\
(0.075)^{* * *}\end{array}$ & $\begin{array}{l}\mathbf{- 0 . 6 3} \\
(0.088)^{* * *}\end{array}$ & $\begin{array}{l}\mathbf{- 0 . 5 7} \\
(0.079)^{* * *}\end{array}$ \\
\hline Subsample: men & $\begin{array}{l}\text { Cyclicality } \\
\text { (s.e.) }\end{array}$ & $\begin{array}{l}-\mathbf{0 . 5 7} \\
(0.065)^{* * *}\end{array}$ & $\begin{array}{l}\mathbf{- 0 . 6 5} \\
(0.066)^{* * *}\end{array}$ & $\begin{array}{l}-\mathbf{0 . 6 2} \\
(0.078)^{* * *}\end{array}$ & $\begin{array}{l}\mathbf{- 0 . 6 1} \\
(0.064)^{* * *}\end{array}$ \\
\hline Subsample: full-time workers & $\begin{array}{l}\text { Cyclicality } \\
\text { (s.e.) }\end{array}$ & $\begin{array}{l}-\mathbf{- 0 . 5 4} \\
(0.073)^{* \star *}\end{array}$ & $\begin{array}{l}\mathbf{- 0 . 6 7} \\
(0.067)^{\star \star *}\end{array}$ & $\begin{array}{l}\mathbf{- 0 . 6 4} \\
(0.085)^{* * *}\end{array}$ & $\begin{array}{l}\mathbf{- 0 . 5 8} \\
(0.062)^{* * *}\end{array}$ \\
\hline Subsample: some college or more & $\begin{array}{l}\text { Cyclicality } \\
\text { (s.e.) }\end{array}$ & $\begin{array}{l}\mathbf{- 0 . 6 3} \\
(0.083)^{* \star * *}\end{array}$ & $\begin{array}{l}\mathbf{- 0 . 7 1} \\
(0.089)^{*+*}\end{array}$ & $\begin{array}{l}\mathbf{- 0 . 7 6} \\
(0.074)^{* * *}\end{array}$ & $\begin{array}{l}\mathbf{- 0 . 5 9} \\
(0.080)^{* * * *}\end{array}$ \\
\hline $\begin{array}{l}\text { Subsample: not manufacturing and } \\
\text { not construction }\end{array}$ & $\begin{array}{l}\text { Cyclicality } \\
\text { (s.e.) }\end{array}$ & $\begin{array}{l}-\mathbf{- 0 . 6 0} \\
(0.076)^{* * * *}\end{array}$ & $\begin{array}{l}\mathbf{- 0 . 7 4} \\
(0.081)^{* * *}\end{array}$ & $\begin{array}{l}\mathbf{- 0 . 6 6} \\
(0.074)^{\star * \star}\end{array}$ & $\begin{array}{l}\mathbf{- 0 . 6 6} \\
(0.096)^{* * *}\end{array}$ \\
\hline $\begin{array}{l}\text { Filtering: HP-filtered with smoothing } \\
\text { parameter } 14400\end{array}$ & $\begin{array}{l}\text { Cyclicality } \\
\text { (s.e.) }\end{array}$ & $\begin{array}{l}\mathbf{- 0 . 6 2} \\
(0.143)^{* * *}\end{array}$ & $\begin{array}{l}\mathbf{- 0 . 5 6} \\
(0.154)^{\star \star \star}\end{array}$ & $\begin{array}{l}\mathbf{- 0 . 6 5} \\
(0.143)^{* * \star}\end{array}$ & $\begin{array}{l}\mathbf{- 0 . 5 4} \\
(0.127)^{\star \star \star}\end{array}$ \\
\hline $\begin{array}{l}\text { Filtering: Not filtered, but controlling } \\
\text { for linear trend }\end{array}$ & $\begin{array}{l}\text { Cyclicality } \\
\text { (s.e.) }\end{array}$ & $\begin{array}{l}\mathbf{- 0 . 6 7} \\
(0.043)^{*+* *}\end{array}$ & $\begin{array}{l}-\mathbf{0 . 6 5} \\
(0.062)^{* * *}\end{array}$ & $\begin{array}{l}\mathbf{- 0 . 7 2} \\
(0.048)^{* * *}\end{array}$ & $\begin{array}{l}\mathbf{- 0 . 6 1} \\
(0.050)^{* * *}\end{array}$ \\
\hline Adjusted for time aggregation bias & $\begin{array}{l}\text { Cyclicality } \\
\text { (s.e.) }\end{array}$ & $\begin{array}{l}\mathbf{0 . 2 9} \\
(0.080)^{\star \star \star *}\end{array}$ & $\begin{array}{l}\mathbf{0 . 6 0} \\
(0.104)^{* \star *}\end{array}$ & $\begin{array}{c}\mathbf{0 . 3 0} \\
(0.067)^{* * *}\end{array}$ & $\begin{array}{l}\mathbf{0 . 5 5} \\
(0.082)^{* * *}\end{array}$ \\
\hline $\begin{array}{l}\text { Notes: Newey-West corrected standard err } \\
\text { significant at } 1 \% \text {. All series are HP-filterec } \\
\text { cylicality is measured as the coefficient } \beta \\
\text { job-finding or unemployment rate of group } \\
\text { Chang and Kim (2009), I instrument the s. } \\
\text { of measurement error. Sample size: } 322 \mathrm{~m} \\
\text { CPS Out going Rotation Group and CPS mo }\end{array}$ & $\begin{array}{l}\text { ors in parenthe } \\
d \text { with a smootl } \\
\text { in the regressio } \\
\text { p i at time t an } \\
\text { ample unemplo } \\
\text { onthly observa } \\
\text { onthly files for }\end{array}$ & $\begin{array}{l}\mathrm{g}(\mathrm{xit})=\alpha+ \\
\text { is the sam } \\
\text { ent rate wi }\end{array}$ & unemplo & $\begin{array}{l}\text { ificant at } \\
\text { s otherwis } \\
\text { e xit is th } \\
\text { rate. Sim } \\
\text { aploymen } \\
\text { ates with c }\end{array}$ & $\begin{array}{l}* * * \\
\text { ted). The } \\
\text { paration, } \\
\text { to Bils, } \\
\text { e because } \\
\text { from the }\end{array}$ \\
\hline
\end{tabular}


Table A.3 The cyclicality of unemployment rates, by wage group (robustness checks)

\begin{tabular}{|c|c|c|c|c|c|}
\hline & & $\underline{\log (h o u}$ & $\mathrm{y}$ wage) & Mince & sidual \\
\hline & & low & high & low & high \\
\hline Full sample (Baseline) & $\begin{array}{l}\text { Cyclicality } \\
\text { (s.e.) }\end{array}$ & $\begin{array}{c}\mathbf{0 . 8 1} \\
(0.024)^{\star \star *}\end{array}$ & $\begin{array}{c}1.25 \\
(0.030)^{*+\alpha}\end{array}$ & $\begin{array}{c}\mathbf{0 . 8 9} \\
(0.025)^{\star k \hbar k}\end{array}$ & $\begin{array}{c}1.13 \\
(0.031)^{*+*+1}\end{array}$ \\
\hline $\begin{array}{l}\text { Extended sample: Unemployed AND } \\
\text { out of the labor force }\end{array}$ & $\begin{array}{l}\text { Cyclicality } \\
\text { (s.e.) }\end{array}$ & $\begin{array}{l}\mathbf{0 . 2 0} \\
(0.022)^{\star \star \star * k}\end{array}$ & $\begin{array}{c}\mathbf{0 . 5 3} \\
(0.037)^{\star \star \star *}\end{array}$ & $\begin{array}{l}\mathbf{0 . 2 4} \\
(0.020)^{* * *}\end{array}$ & $\begin{array}{l}\mathbf{0 . 4 1} \\
(0.033)^{* * *}\end{array}$ \\
\hline $\begin{array}{l}\text { Subsample: not on temporary layoff } \\
\text { (1988-2008 only) }\end{array}$ & $\begin{array}{l}\text { Cyclicality } \\
\text { (s.e.) }\end{array}$ & $\begin{array}{l}\mathbf{0 . 8 1} \\
(0.049)^{* * *}\end{array}$ & $\begin{array}{l}1.34 \\
(0.069)^{* k *}\end{array}$ & $\begin{array}{l}\mathbf{0 . 9 0} \\
(0.053)^{* * *}\end{array}$ & $\begin{array}{l}\mathbf{1 . 2 0} \\
(0.056)^{* k *}\end{array}$ \\
\hline Subsample: age $25-54$ & $\begin{array}{l}\text { Cyclicality } \\
\text { (s.e.) }\end{array}$ & $\begin{array}{c}\mathbf{0 . 8 0} \\
(0.022)^{* * *}\end{array}$ & $\begin{array}{l}1.23 \\
(0.026)^{* * *}\end{array}$ & $\begin{array}{l}\mathbf{0 . 8 9} \\
(0.028)^{* * *}\end{array}$ & $\begin{array}{l}1.13 \\
(0.034)^{* * *}\end{array}$ \\
\hline Subsample: men & $\begin{array}{l}\text { Cyclicality } \\
\text { (s.e.) }\end{array}$ & $\begin{array}{c}\mathbf{0 . 7 9} \\
(0.033)^{*+* k}\end{array}$ & $\begin{array}{l}\mathbf{1 . 1 8} \\
(0.027)^{* \star *}\end{array}$ & $\begin{array}{l}\mathbf{0 . 8 6} \\
(0.029)^{* * *}\end{array}$ & $\frac{1.16}{(0.033)^{\star * \star *}}$ \\
\hline Subsample: full-time workers & $\begin{array}{l}\text { Cyclicality } \\
\text { (s.e.) }\end{array}$ & $\begin{array}{c}\mathbf{0 . 8 0} \\
(0.027)^{* * *}\end{array}$ & $\begin{array}{c}1.21 \\
(0.028)^{* * *}\end{array}$ & $\begin{array}{l}\mathbf{0 . 8 9} \\
(0.026)^{* * *}\end{array}$ & $\begin{array}{l}1.11 \\
(0.028)^{* * *}\end{array}$ \\
\hline Subsample: some college or more & $\begin{array}{l}\text { Cyclicality } \\
\text { (s.e.) }\end{array}$ & $\begin{array}{l}\mathbf{0 . 8 2} \\
(0.046)^{* * *}\end{array}$ & $\begin{array}{l}\mathbf{1 . 1 5} \\
(0.037)^{* * *}\end{array}$ & $\begin{array}{l}\mathbf{0 . 9 5} \\
(0.033)^{* * *}\end{array}$ & $\begin{array}{l}1.06 \\
(0.040)^{* * * *}\end{array}$ \\
\hline $\begin{array}{l}\text { Subsample: not manufacturing and } \\
\text { not construction }\end{array}$ & $\begin{array}{l}\text { Cyclicality } \\
\text { (s.e.) }\end{array}$ & $\begin{array}{l}\mathbf{0 . 8 2} \\
(0.025)^{* \star * *}\end{array}$ & $\frac{1.26}{(0.036)^{* * *}}$ & $\begin{array}{l}\mathbf{0 . 8 7} \\
(0.029)^{* k *}\end{array}$ & $\frac{1.15}{(0.037)^{* * *}}$ \\
\hline $\begin{array}{l}\text { Filtering: HP-filtered with smoothing } \\
\text { parameter } 14400\end{array}$ & $\begin{array}{l}\text { Cyclicality } \\
\text { (s.e.) }\end{array}$ & $\begin{array}{c}\mathbf{0 . 8 1} \\
(0.050)^{* * *}\end{array}$ & $\underset{(0.063)^{* * *}}{1.22}$ & $\begin{array}{l}\mathbf{0 . 8 6} \\
(0.051)^{* * *}\end{array}$ & $\frac{1.16}{(0.065)^{*+k+}}$ \\
\hline $\begin{array}{l}\text { Filtering: Not filtered, but controlling } \\
\text { for linear trend }\end{array}$ & $\begin{array}{l}\text { Cyclicality } \\
\text { (s.e.) }\end{array}$ & $\begin{array}{c}\mathbf{0 . 8 4} \\
(0.023)^{*+* *}\end{array}$ & $\underset{(0.030)^{* * *}}{1.22}$ & $\begin{array}{l}\mathbf{0 . 8 9} \\
(0.023)^{* * *}\end{array}$ & $\begin{array}{l}1.13 \\
(0.028)^{*+*+}\end{array}$ \\
\hline $\begin{array}{l}\text { Notes: Newey-West corrected standard err } \\
\text { significant at } 1 \% \text {. All series are HP-filtered } \\
\text { cylicality is measured as the coefficient } \beta \text { i } \\
\text { job-finding or unemployment rate of group } \\
\text { Chang and Kim (2009), I instrument the sa } \\
\text { of measurement error. Sample size: } 322 \mathrm{~m} \\
\text { CPS Outooing Rotation Groun and CPS mo }\end{array}$ & $\begin{array}{l}\text { ors in parenthe } \\
\text { d with a smooth } \\
\text { in the regressio } \\
\text { p i at time } t \text { anc } \\
\text { ample unemplo }\end{array}$ & $\begin{array}{l}\text { is the sar } \\
\text { nt rate }\end{array}$ & $\begin{array}{l}\text { (Ut })+\varepsilon i t \\
\text { inemploy } \\
\text { e officia }\end{array}$ & $\begin{array}{l}\text { xit is } t \\
\text { rate. Sir } \\
\text { ployme }\end{array}$ & $\begin{array}{l}* * * \\
\text { ated). The } \\
\text { paration, } \\
\text { to Bils, } \\
\text { e because } \\
\text { from the }\end{array}$ \\
\hline
\end{tabular}


Table A.4 The cyclicality of separation and job-finding rates, by wage group (quartiles)

Panel A. Log(hourly wage)

\begin{tabular}{|c|c|c|c|c|c|}
\hline & & $1 s t$ & $2 n d$ & $3 r d$ & 4 th \\
\hline Separations & $\begin{array}{l}\text { Cyclicality } \\
\text { (s.e.) }\end{array}$ & $\begin{array}{c}\mathbf{0 . 2 9} \\
(0.117)^{* *}\end{array}$ & $\begin{array}{c}\mathbf{0 . 5 5} \\
(0.085)^{\star \star \star}\end{array}$ & $\begin{array}{l}\mathbf{0 . 6 8} \\
(0.109)^{\star \star * *}\end{array}$ & $\begin{array}{c}\mathbf{0 . 8 2} \\
(0.128)^{\star \star \star}\end{array}$ \\
\hline Job findings & $\begin{array}{l}\text { Cyclicality } \\
\text { (s.e.) }\end{array}$ & $\begin{array}{c}\mathbf{- 0 . 4 9} \\
(0.058)^{\star \star \star *}\end{array}$ & $\begin{array}{c}\mathbf{- 0 . 6 3} \\
(0.079)^{* \star \star}\end{array}$ & $\begin{array}{c}\mathbf{- 0 . 6 6} \\
(0.078)^{*+* t}\end{array}$ & $\begin{array}{c}\mathbf{- 0 . 6 9} \\
(0.093)^{\star * *}\end{array}$ \\
\hline \multirow[t]{3}{*}{ Unemployment } & $\begin{array}{l}\text { Cyclicality } \\
\text { (s.e.) }\end{array}$ & $\begin{array}{c}\mathbf{0 . 6 7} \\
(0.044)^{* * *}\end{array}$ & $\begin{array}{c}\mathbf{0 . 9 9} \\
(0.035)^{*+*}\end{array}$ & $\begin{array}{c}1.24 \\
(0.061)^{* \star *}\end{array}$ & $\begin{array}{c}1.27 \\
(0.058)^{* \star \star \star}\end{array}$ \\
\hline & & \multicolumn{4}{|c|}{$\underline{\text { Panel B. Mincer-residual }}$} \\
\hline & & $1 s t$ & $2 n d$ & 3rd & $4 t h$ \\
\hline Separations & $\begin{array}{l}\text { Cyclicality } \\
\text { (s.e.) }\end{array}$ & $\begin{array}{c}\mathbf{0 . 3 9} \\
(0.100)^{\star \star \star}\end{array}$ & $\begin{array}{c}\mathbf{0 . 4 7} \\
(0.083)^{* \star \star}\end{array}$ & $\begin{array}{c}\mathbf{0 . 7 4} \\
(0.092)^{* * *}\end{array}$ & $\begin{array}{c}\mathbf{0 . 6 5} \\
(0.106)^{\star \star \star k \hbar}\end{array}$ \\
\hline Job findings & $\begin{array}{l}\text { Cyclicality } \\
\text { (s.e.) }\end{array}$ & $\begin{array}{c}\mathbf{- 0 . 6 6} \\
(0.068)^{* \star * *}\end{array}$ & $\begin{array}{l}\mathbf{- 0 . 6 3} \\
(0.120)^{* \star *}\end{array}$ & $\begin{array}{l}\mathbf{- 0 . 6 2} \\
(0.128)^{\star \star \star \star}\end{array}$ & $\begin{array}{c}\mathbf{- 0 . 5 6} \\
(0.103)^{\star \star \star}\end{array}$ \\
\hline Unemployment & $\begin{array}{l}\text { Cyclicality } \\
\text { (s.e.) }\end{array}$ & $\begin{array}{c}\mathbf{0 . 8 6} \\
(0.037)^{*+k}\end{array}$ & $\begin{array}{c}\mathbf{0 . 9 2} \\
(0.052)^{\star \star \star *}\end{array}$ & $\begin{array}{c}1.17 \\
(0.036)^{*+* k}\end{array}$ & $\begin{array}{c}\mathbf{1 . 1 1} \\
(0.062)^{\star \star \star}\end{array}$ \\
\hline
\end{tabular}

Notes: Newey-West corrected standard errors in parentheses; $*$ significant at $10 \%$; ** significant at $5 \%$; $* * *$ significant at $1 \%$. All series are HP-filtered with a smoothing parameter of 900,000 . The cylicality is measured as the coefficient $\beta$ in the regression $\log (\mathrm{xit})=\alpha+\beta \log (\mathrm{Ut})+\varepsilon$ it, where $\mathrm{xit}$ is the separation, hiring or unemployment rate of group $i$ at time $t$ and $U t$ is the sample unemployment rate. Similar to Bils, Chang and Kim (2009), I instrument the sample unemployment rate with the official unemployment rate because of measurement error. Sample size: 322 monthly observations. Source: The author's estimates with data from the CPS Outgoing Rotation Group and CPS monthly files for the years 1979-2008. 
Table A.5 Comparative statics results : baseline calibration

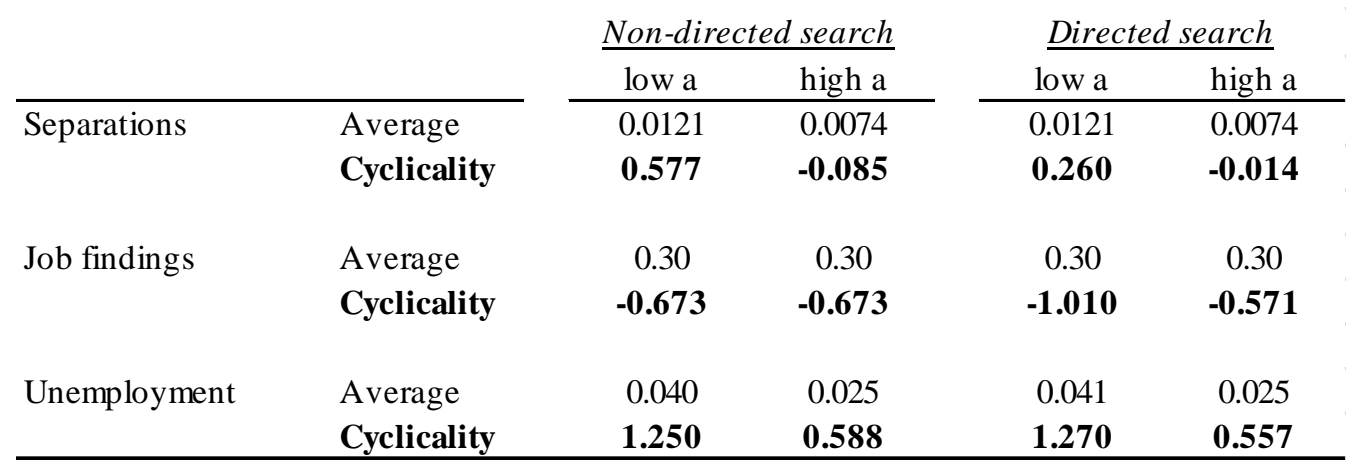

Table A.6 Comparative statics results: model with firm and plant death

\begin{tabular}{|c|c|c|c|c|c|}
\hline & & \multicolumn{2}{|c|}{ Non-directed search } & \multicolumn{2}{|c|}{ Directed search } \\
\hline & & low a & high a & low a & high a \\
\hline \multirow[t]{2}{*}{ Separations } & Average & 0.0146 & 0.0095 & 0.0146 & 0.0095 \\
\hline & Cyclicality & 0.800 & 0.983 & 0.717 & 0.951 \\
\hline \multirow[t]{2}{*}{ Job findings } & Average & 0.30 & 0.30 & 0.30 & 0.30 \\
\hline & Cyclicality & -0.128 & -0.128 & -0.225 & -0.140 \\
\hline \multirow[t]{2}{*}{ Unemployment } & Average & 0.049 & 0.032 & 0.049 & 0.032 \\
\hline & Cyclicality & 0.928 & 1.111 & 0.942 & 1.090 \\
\hline
\end{tabular}

Table A.7 Comparative statics results: model with credit-constraint $\operatorname{shocks}(\gamma=\mathbf{- 0 . 0 5})$

\begin{tabular}{|c|c|c|c|c|c|}
\hline & & \multicolumn{2}{|c|}{ Non-directed search } & \multicolumn{2}{|c|}{ Directed search } \\
\hline & & low a & high a & low a & high a \\
\hline \multirow[t]{2}{*}{ Separations } & Average & 0.0123 & 0.0082 & 0.0123 & 0.0081 \\
\hline & Cyclicality & 0.538 & 1.266 & 0.363 & 1.095 \\
\hline \multirow[t]{2}{*}{ Job findings } & Average & 0.30 & 0.30 & 0.30 & 0.30 \\
\hline & Cyclicality & -0.174 & -0.174 & -0.417 & -0.239 \\
\hline \multirow[t]{2}{*}{ Unemployment } & Average & 0.041 & 0.027 & 0.041 & 0.027 \\
\hline & Cyclicality & 0.711 & 1.439 & 0.780 & 1.334 \\
\hline
\end{tabular}

